\title{
Neogene Caribbean elasmobranchs: diversity, paleoecology and paleoenvironmental significance of the Cocinetas Basin assemblage (Guajira Peninsula, Colombia)
}

\author{
Jorge Domingo Carrillo-Briceño ${ }^{1,2}$, Zoneibe Luz $^{3}$, Austin Hendy ${ }^{4}$, László Kocsis ${ }^{5}$, Orangel Aguilera ${ }^{6}$, and \\ Torsten Vennemann ${ }^{3}$ \\ ${ }^{1}$ Palaeontological Institute and Museum, University of Zurich, Karl-Schmid-Strasse 4, 8006 Zurich, Switzerland \\ ${ }^{2}$ Smithsonian Tropical Research Institute, Av. Gorgas, Ed. 235, 0843-03092 Balboa, Ancón, Panama \\ ${ }^{3}$ Institut des Dynamiques de la Surface Terrestre, Université de Lausanne, Rue de la Mouline, 1015 Lausanne, France \\ ${ }^{4}$ Natural History Museum of Los Angeles County, 900 Exposition Blvd, Los Angeles, California 90007, USA \\ ${ }^{5}$ Universiti Brunei Darussalam, Faculty of Science, Geology Group, Jalan Tungku, BE 1410, Brunei Darussalam \\ ${ }^{6}$ Departamento de Biologia Marinha, Instituto de Biologia, Universidade Federal Fluminense, Niterói, \\ 24020-150 Rio de Janeiro, Brazil
}

Correspondence: Zoneibe Luz (zoneibe.luz@gmail.com)

Received: 6 June 2018 - Discussion started: 14 June 2018

Revised: 22 October 2018 - Accepted: 30 November 2018 - Published: 8 January 2019

\begin{abstract}
The Cocinetas Basin is located on the eastern flank of the Guajira Peninsula, northern Colombia (southern Caribbean). During the late Oligocene through the Pliocene, much of the basin was submerged. The extensive deposits in this area suggest a transition from a shallow marine to a fluvio-deltaic system, with a rich record of invertebrate and vertebrate fauna. The elasmobranch assemblages of the early Miocene to the late Pliocene succession in the Cocinetas Basin (Jimol, Castilletes and Ware formations, as well as the Patsúa Valley) are described for the first time. The assemblages include at least 30 taxa of sharks (Squaliformes, Pristiophoriformes, Orectolobiformes, Lamniformes and Carcharhiniformes) and batoids (Rhinopristiformes and Myliobatiformes), of which 24 taxa are reported from the Colombian Neogene for the first time. Paleoecological interpretations are based on the feeding ecology and on estimates of the paleohydrology (relative salinity, temperature) using stable isotope compositions of oxygen in the bioapatite of shark teeth. The isotopic composition of the studied specimens corroborates paleoenvironmental settings for the studied units that were previously estimated based on the sedimentology and biology of the taxa. These Neogene elasmobranch assemblages from the Cocinetas Basin provide new insights into the diversity the sharks and rays inhabiting the coastal and estuarine environments of the northwestern margin of
\end{abstract}

South America, both during the existence of the gateway between the Atlantic and Pacific oceans and following its closure.

\section{Introduction}

During the Neogene, large areas of the northern margin of South America were submerged (see Iturralde-Vinent and MacPhee, 1999) and influenced by the paleoceanographic connection between the Pacific and Atlantic oceans along the Central American Seaway (CAS). The CAS is defined here as a deep oceanic connection between the Pacific and Atlantic oceans along the tectonic boundary of the Caribbean and South American plates (Jaramillo et al., 2017). The CAS existed throughout the Cenozoic, but was reduced in width by the early Miocene (Farris et al., 2011), and the transfer of deep water ceased by the late Miocene 12-10 Ma (Montes et al., 2015; Bacon et al., 2015; Jaramillo et al., 2017). Shallow marine connections between Caribbean and Pacific waters existed until about 4.2-3.5 Ma, when a complete closure occurred (Coates and Stallard, 2013). The Cocinetas Basin, located on the eastern flank of the Guajira Peninsula, northern Colombia, records a transition in marine and terrestrial paleoenvironments during this regional change in conditions. 
This region presents extensive and well-exposed sedimentary deposits spanning the last $25 \mathrm{Myr}$ (Moreno et al., 2015). The paleoenvironments are characterized by a transition from shallow marine deposits to a fluvio-deltaic system (Moreno et al., 2015), with a rich fossil record of invertebrates (Hendy et al., 2015) and vertebrates (Aguilera et al., 2013; Aguilera et al., 2017b; Moreno et al., 2015; Cadena and Jaramillo, 2015; Amson et al., 2016; Carrillo-Briceño et al., 2016b; Moreno-Bernal et al., 2016; Pérez et al., 2016). Ages for many of the fossiliferous units in the sequence have been estimated using Sr isotope stratigraphy (see Hendy et al., 2015).

Neogene marine chondrichthyan faunas from the southern proto-Caribbean (especially from the northern margin of South America) are well known from Venezuela and the Lesser Antilles (e.g., Leriche, 1938; Casier, 1958, 1966; Aguilera, 2010; Aguilera and Lundberg, 2010; CarrilloBriceño et al., 2015b, 2016a, and references therein). But reports on chondrichthyans from the Neogene of Colombia are scarce. Previous reports from the Cocinetas Basin include fossil elasmobranchs without taxonomic description (Lockwood, 1965), a checklist of 14 families (Moreno et al., 2015) and the description of a small assemblage of 13 taxa from the early Miocene Uitpa Formation (Carrillo-Briceño et al., 2016b).

A taxonomic list is presented of the elasmobranch fauna collected in the Cocinetas Basin (Figs. 1-2), from the Jimol (Burdigalian), Castilletes (late Burdigalian-Langhian) and Ware (Gelasian-Piacenzian) formations and two localities of the Patsúa Valley (Burdigalian-Langhian). The assemblage includes 30 taxa, of which 24 are new reports for Colombian Neogene deposits. Additionally, paleoecological and paleoenvironmental interpretations based on the feeding ecology of extant counterpart species, as well as measurements of the ratio of stable oxygen isotopes in the bioapatite of shark teeth, are discussed. The Cocinetas Basin represents a valuable window into dynamic changes in paleodiversity experienced by ancient proto-Caribbean Neogene chondrichthyan faunas.

\section{Material and methods}

The fossil elasmobranch assemblages (Table 1, Tables S1S3; File S4 in the Supplement) consist of 2529 specimens from 36 localities (Table S1) from the Cocinetas Basin, Guajira Peninsula, northeastern Colombia (Fig. 1). The elasmobranch faunas were collected in the early Miocene Jimol Formation (6 localities and 113 specimens), early-middleMiocene Castilletes Formation (20 localities and 1232 specimens) and the late Pliocene Ware Formation (8 localities and 215 specimens) (Tables S1-S2). Localities STRI 290468 and 290472 (968 specimens) in the Patsúa Valley, close to Flor de la Guajira, along the southern margin of the Cocinetas Basin (Fig. 1) are from strata with distinct paleofauna and facies from those of the Jimol and Castilletes formations. They are considered as the undifferentiated Jimol and Castilletes Formation and are referred to herein as the Patsúa assemblage.

The samples were collected by JDCB, AH and other collaborators during several expeditions between 2010 and 2014. Large specimens were surface collected and $50 \mathrm{~kg}$ of bulk sediment was collected, sieved and screen washed (mesh sizes: 0.5 and $2 \mathrm{~mm}$ ) for subsequent picking of smaller specimens from the localities 290468 (Patsúa assemblage), 290632 and 390094 (Castilletes Formation).

The Cocinetas Basin elasmobranch specimens (File S4) are housed in the paleontological collections of the Mapuka Museum of Universidad del Norte (MUN), Barranquilla, Colombia. Nomenclature follows Cappetta (2012) and Compagno (2005), with the exception of Rhinopristiformes Last et al., 2016, Aetobatidae Agassiz, 1958 (Table 1) and Carcharocles Agassiz, 1838, for which we follow the nomenclature discussed in Last et al. (2016), White and Naylor (2016) and Ward and Bonavia (2001), respectively. Identifications are based on literature review (e.g., Santos and Travassos, 1960; Müller, 1999; Purdy et al., 2001; Cappetta, 1970, 2012; Reinecke et al., 2011; Reinecke et al., 2014; Voigt and Weber, 2011; Bor et al., 2012; Carrillo-Briceño et al., 2014, 2015a, b, 2016b, a; Aguilera et al., 2017a, among others) and comparative analysis between fossil and extant specimens from several collections including the Museu Paraense Emílio Goeldi (MPEGV), Belém, Brazil; Fossil Vertebrate Section of the Museum für Naturkunde, Berlin, Germany (MB.Ma.); Natural History Museum of Basel (NMB), Switzerland; paleontological collections of the Alcaldía del Municipio Urumaco (AMUCURS) and Centro de Investigaciones Antropológicas, Arqueológicas y Paleontológicas of the Universidad Experimental Francisco de Miranda (CIAAP, UNEFM-PF), both in Venezuela; Paleontological collection of the Institut des Sciences de l'Evolution, University of Montpellier (UM), France; and the Palaeontological Institute and Museum at the University of Zurich (PIMUZ) and the René Kindlimann private collection, Uster, Switzerland.

Quantitative data includes percentages of specimens by order, family and genus recorded in the overall assemblages of the Cocinetas Basin (Table 1, Tables S1-S2, Fig. S5). Extant sharks and rays as a whole have a wide range of diets; however, each taxon has specific food preferences (see Cortés et al., 2008; Klimley, 2013) that could be used to infer dietary strategies of their fossil relatives (e.g., Carrillo-Briceño et al., 2016a). Information regarding feeding ecology (dietary composition and behavior) of extant and relative species of the taxa recorded in the Cocinetas assemblages (Table S3) was compiled from Cortés et al. (2008), Compagno et al. (2005), Voigt and Weber (2011), Ebert and Stehmann (2013) and the FishBase website (Froese and Pauly, 2017). For this paper we treated the term "diversity" as species "richness", since in terms of ecology diversity takes into account the relative abundance of individuals living in a community (Putman and Wratten, 1984). Dealing with fossil taxa 
(a)

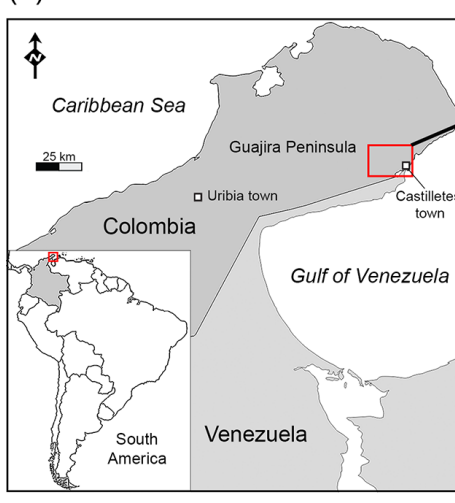

(b)

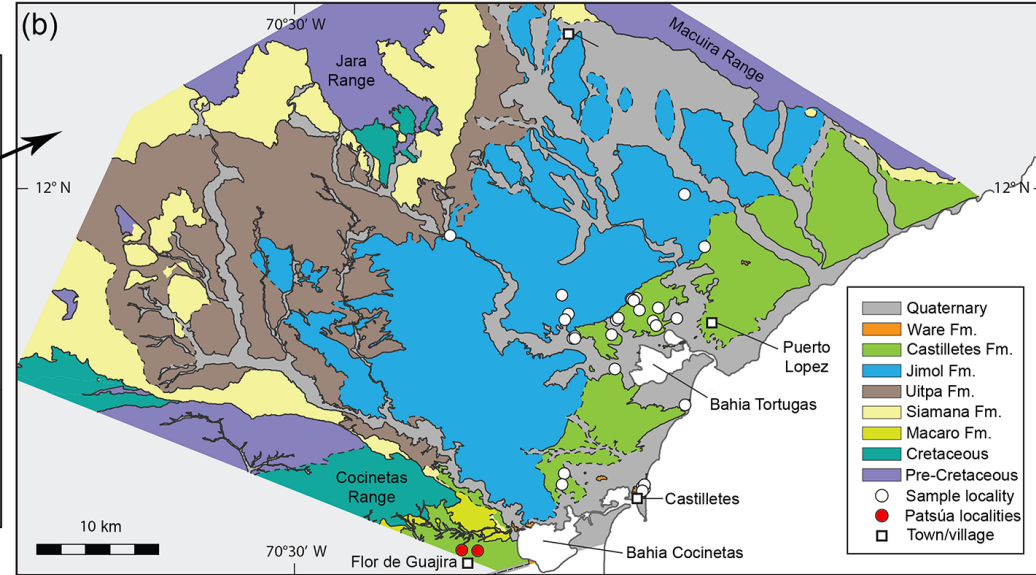

Figure 1. Location (a) and geological map of the southeastern Cocinetas Basin (b). Fm.: Formation.

requires a more careful sampling plan with well-represented layers, but few specimens could be found for some of our studied localities. Therefore, diversity refers to the number of species without considering their abundance. Where the identification was established only to the genus level, we considered that at least one species was present from that group.

Analyses of $\delta^{18} \mathrm{O}_{\mathrm{PO}_{4}}$ were made in the Stable Isotope Laboratory at the University of Lausanne (UNIL) (Table 2). Powder samples of $1-1.5 \mathrm{mg}$ from shark tooth enameloid were obtained by abrasion of the crown surface using a microdrill and small fragment samples were obtained by cutting off the tooth tips. In a few cases when only small or fragmented teeth were available, bulk samples were taken (1$1.5 \mathrm{mg}$ of enameloid and dentine). Based on previous studies, isotopic data provide valuable information about the paleoecology of sharks along stratigraphic sequences (Fischer et al., 2012, 2013a, b; Kocsis et al., 2014; Leuzinger et al., 2015; Aguilera et al., 2017a). All samples were cleaned in deionized water in an ultrasonic bath to reduce sedimentary contamination. International reference (NBS-120c phosphorite) and in-house laboratory standards were prepared in parallel with each sequence of samples. Pretreatment followed the method described by Koch et al. (1997), where powdered teeth were first washed in $1 \mathrm{M}$ acetic acid-Ca acetate $(\mathrm{pH}$ $=4.5,2 \mathrm{~h}$ ) to remove any exogenous carbonates and then were thoroughly rinsed several times in deionized water. To obtain the $\delta^{18} \mathrm{O}_{\mathrm{PO}_{4}}$ values the phosphate group in apatite was separated via precipitation as silver phosphate (O'Neil et al., 1994; Dettman et al., 2001; Kocsis, 2011). The method was adapted from the last review on silver phosphate microprecipitations by Mine et al. (2017). Triplicates or duplicates of each $\mathrm{Ag}_{3} \mathrm{PO}_{4}$ sample were analyzed on a TC/EA (high-temperature conversion elemental analyzer) (Vennemann et al., 2002) coupled to a Finnigan MAT 253 mass spectrometer, where silver phosphate is converted to $\mathrm{CO}$ at $1450^{\circ} \mathrm{C}$ via reduction with graphite. Measurements were corrected to in-house $\mathrm{Ag}_{3} \mathrm{PO}_{4}$ phosphate standards (LK-2L:
$12.1 \%$ and LK-3L: $17.9 \%$ ) that had better than $\pm 0.3 \%$ o $(1 \sigma)$ standard deviations during measurements. The NBS$120 \mathrm{c}$ phosphorite reference material had an average value of $21.7 \% \circ \pm 0.1 \% \circ(n=6)$. The isotope ratios are expressed in the $\delta$ notation relative to Vienna Standard Mean Ocean Water (VSMOW).

The $\delta^{18} \mathrm{O}_{\mathrm{PO}_{4}}$ value in shark teeth is a well-known environmental proxy, especially when enameloid-derived samples are employed (Vennemann et al., 2001; Zazzo et al., 2004a, b; Lécuyer, 2004; Kocsis, 2011). Longinelli and Nuti (1973a, b) recognized that the $\delta^{18} \mathrm{O}_{\mathrm{PO}_{4}}$ values of several ectothermic fishes are related to two environmental parameters: water temperature $(T)$ and the $\delta^{18} \mathrm{O}$ value of the water $\left(\delta^{18} \mathrm{O}_{\mathrm{w}}\right)$. Based on these studies, an equation that empirically represents the oxygen isotope fractionation between biogenic phosphate and water was calculated $\left(\left[T\left({ }^{\circ} \mathrm{C}\right)=111.4-4.3\right.\right.$ $\left.\left(\delta^{18} \mathrm{O}_{\mathrm{PO}_{4}}-\delta^{18} \mathrm{O}_{\mathrm{w}}\right)\right]$ ), which was later revised (Kolodny et al., 1983; Pucéat et al., 2010; Lécuyer et al., 2013). This equation is used by paleontologists as a paleothermometer (Barrick et al., 1993; Lécuyer et al., 1993, 1996). Recently the $\delta^{18} \mathrm{OPO}_{4}$ values have also been used to estimate the horizontal migrations of fishes into brackish environments (Kocsis et al., 2007; Klug et al., 2010; Fischer et al., 2012, 2013a, b; Leuzinger et al., 2015).

Paleotemperatures from the $\delta^{18} \mathrm{O}_{\mathrm{PO}_{4}}$ values were also calculated using the latest equation of Lécuyer et al. (2013) $\left[T\left({ }^{\circ} \mathrm{C}\right)=117.4-4.5 \times\left(\delta^{18} \mathrm{O}_{\mathrm{PO}_{4}}-\delta^{18} \mathrm{O}_{\mathrm{w}}\right)\right]$. For the late Pliocene samples (Ware Formation) a seawater value of $0 \%$ was used (Vienna Standard Mean Ocean Water), while for the early-middle-Miocene samples (Patsúa assemblage, Jimol and Castilletes) a value of $-0.4 \%$ was used following estimates of the global seawater isotopic composition (Lear et al., 2000; Billups and Schrag, 2002). 

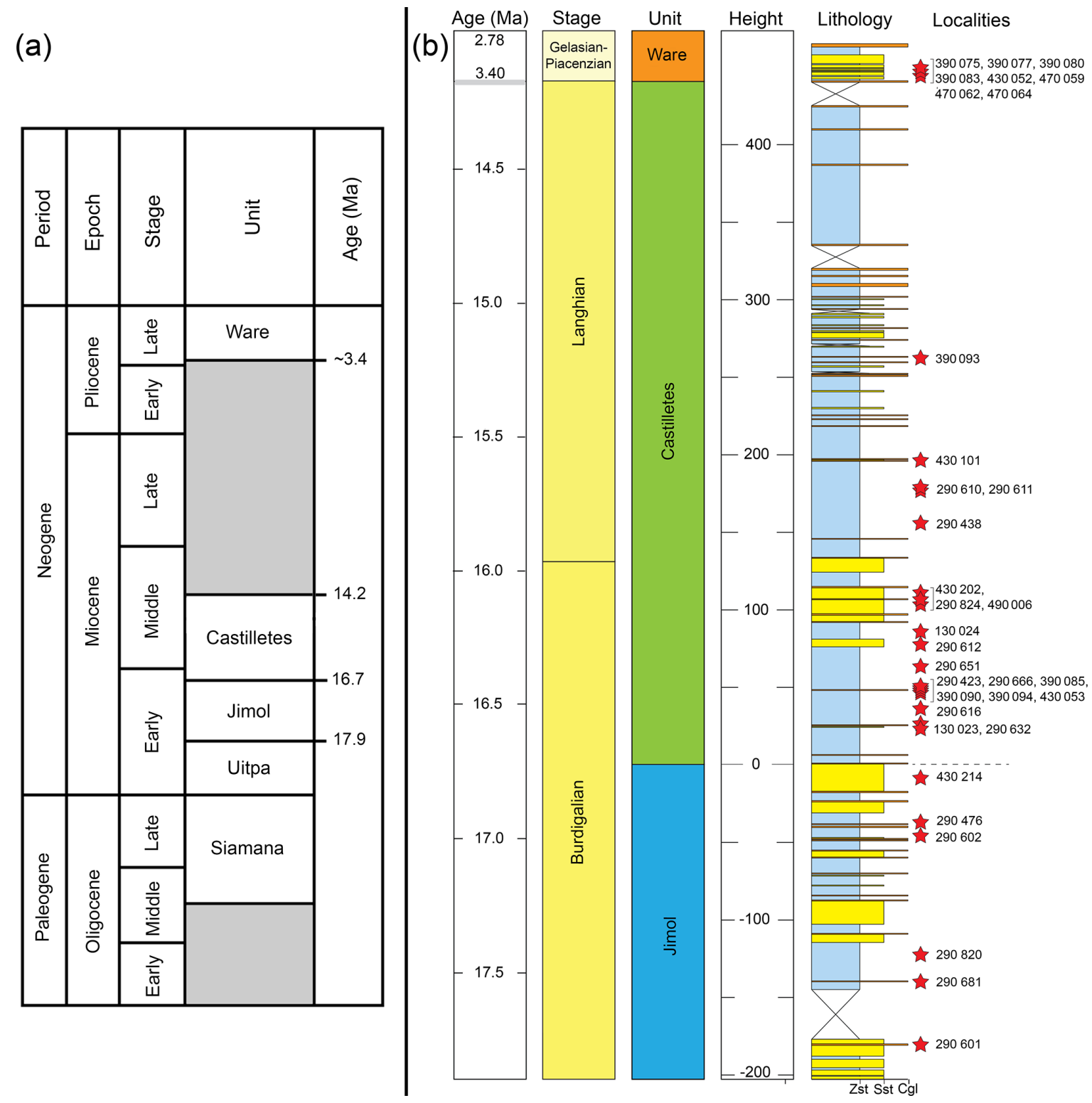

Figure 2. Stratigraphy of the Cocinetas Basin. (a) Generalized stratigraphy (after Moreno et al., 2015). (b) Stratigraphic section and studied localities. Localities of the Patsúa Valley (290468 and 290472) (details in Table S1) are not represented, because these localities belong to another section of the basin without stratigraphic column.

\section{Geological and stratigraphic setting}

\subsection{Jimol Formation (Burdigalian)}

This formation is one of the most extensive Cenozoic units in the Cocinetas Basin (Fig. 1b), with a thickness of approximately $203 \mathrm{~m}$. However, the formation is represented by a composite section with some poorly preserved beds in the middle portion (Moreno et al., 2015). The lower and upper contacts of the Jimol Formation are conformable with the Uitpa and Castilletes formations, respectively (Fig. 1b). According to Moreno et al. (2015) and Hendy et al. (2015), the unit is characterized by coarse detritic and calcareous lithologies with few interbedded muddy levels deposited in a shallow marine paleoenvironment, likely an inner shelf environment $(<50 \mathrm{~m})$. Abundant invertebrates (Hendy et al., 2015) and some vertebrate remains (Moreno et al., 2015; Moreno-Bernal et al., 2016) have been recorded. A late early Miocene (17.9-16.7 Ma) age is assigned to the unit on the basis of macroinvertebrate biostratigraphy and ${ }^{87} \mathrm{Sr} /{ }^{86} \mathrm{Sr}$ isotope chronostratigraphy (see Hendy et al., 2015). 
Table 1. Elasmobranchii paleodiversity of the Cocinetas Basin.

\begin{tabular}{|c|c|c|c|c|}
\hline Superorder & Order & Family & Genus & Taxon \\
\hline \multirow[t]{2}{*}{ Squalomorphii } & Squaliformes & Dalatiidae & Dalatias & Dalatias cf. D. licha (Bonnaterre, 1788) \\
\hline & Pristiophoriformes & Pristiophoridae & Pristiophorus & Pristiophorus sp. \\
\hline \multirow[t]{22}{*}{ Galeomorphii } & Orectolobiformes & Ginglymostomatidae & Nebrius & Nebrius sp. \\
\hline & Lamniformes & Lamnidae & Isurus & Isurus cf. I. oxyrinchus Rafinesque, 1810 \\
\hline & & $†$ Otodontidae & $\dagger$ Parotodus & $†$ Parotodus benedenii (Le Hon, 1871) \\
\hline & & & $\dagger$ Carcharocles & $†$ Carcharocles chubutensis (Ameghino, 1901) \\
\hline & & & & $\begin{array}{l}\dagger \text { Carcharocles megalodon (Agassiz, 1843) } \\
\dagger \text { Carcharocles } \mathrm{sp} \text {. }\end{array}$ \\
\hline & & Alopiidae & Alopias & Alopias cf. A. exigua (Probst, 1879) \\
\hline & & & $\dagger$ Anotodus & $\dagger$ †Anotodus retroflexus (Agassiz, 1843) \\
\hline & Carcharhiniformes & Hemigaleidae & Hemipristis & $\dagger$ Hemipristis serra (Agassiz, 1835) \\
\hline & & Carcharhinidae & Galeocerdo & $†$ Galeocerdo mayumbensis Dartevelle and Casier, 1943 \\
\hline & & & Carcharhinus & $†$ Carcharhinus ackermannii Santos and Travassos, 1960 \\
\hline & & & & Carcharhinus cf. C. brachyurus (Günther, 1870) \\
\hline & & & & $†$ Carcharhinus gibbesii (Woodward, 1889) \\
\hline & & & & Carcharhinus leucas (Müller and Henle, 1839) \\
\hline & & & & Carcharhinus cf. C. limbatus (Müller and Henle, 1839) \\
\hline & & & & Carcharhinus cf. C. perezi (Poey, 1868) \\
\hline & & & & Carcharhinus cf. $\dagger$ C. priscus (Agassiz, 1843) \\
\hline & & & & Carcharhinus spp. \\
\hline & & & $\dagger$ †sogomphodon & $†$ Isogomphodon acuarius (Probst, 1879) \\
\hline & & & Negaprion & $†$ Negaprion eurybathrodon (Blake, 1862) \\
\hline & & & $†$ Physogaleus & $\dagger$ Physogaleus contortus (Gibbes, 1849) \\
\hline & & Sphyrnidae & Sphyrna & $†$ Sphyrna arambourgi Cappetta, 1970 \\
\hline & & & & $†$ Sphyrna laevissima (Cope, 1867) \\
\hline \multirow[t]{9}{*}{ Batomorphii } & Rhinopristiformes & Rhynchobatidae & Rhynchobatus & Rhynchobatus sp. \\
\hline & & Pristidae & Pristis & Pristis sp. \\
\hline & Myliobatiformes & Dasyatidae & Dasyatis & Dasyatis sp. \\
\hline & & Aetobatidae & Aetobatus & Aetobatus sp. \\
\hline & & Myliobatidae & Aetomylaeus & Aetomylaeus sp. \\
\hline & & Rhinopteridae & Rhinoptera & Rhinoptera sp. \\
\hline & & & & Myliobatoidea indet. \\
\hline & & Mobulidae & Plinthicus & $†$ Plinthicus stenodon Cope, 1869 \\
\hline & & & & Myliobatiformes indet. \\
\hline
\end{tabular}

\subsection{Castilletes Formation (Burdigalian-Langhian)}

This lithostratigraphic unit crops out along the eastern margin of the Cocinetas Basin (Fig. 1b). The lithology of the Castilletes Formation is characterized by successions of mudstones interbedded with thin beds of biosparites and sandstones, with an estimated thickness of $440 \mathrm{~m}$. The lower contact is conformable with the underlying Jimol Formation and the upper is unconformable (angular contact) with the overlying Ware Formation (Moreno et al., 2015). The unit was deposited in shallow marine to fluvio-deltaic environments, with abundant marine, fluviolacustrine and terrestrial fossils (e.g., plants, mollusks, crustaceans, fishes, turtles, crocodilians and mammals) (Aguilera et al., 2013; Aguilera et al., 2017b; Cadena and Jaramillo, 2015; Hendy et al., 2015; Moreno et al., 2015; Amson et al., 2016; MorenoBernal et al., 2016; Aguirre-Fernández et al., 2017). Isotope chronostratigraphy $\left({ }^{87} \mathrm{Sr} /{ }^{86} \mathrm{Sr}\right.$ ) supports an age of $16.2 \mathrm{Ma}$ (range: 16.33-16.07) for the lower section and $15.30 \mathrm{Ma}$ (range: 15.14-15.43) for the middle part of the unit (Moreno et al., 2015).

\subsection{Undifferentiated Jimol and Castilletes Formation (Burdigalian-Langhian)}

Sediments of Bahía Cocinetas in the Patsúa Valley were previously mapped as the Castilletes Formation (Moreno et al., 2015; Moreno-Bernal et al., 2016). They overlay the carbonates of the Siamana Formation, in places with an irregular contact relationship (unconformably or conformably), and are in turn overlain by sediments of the Ware Formation but with an angular unconformity. These relationships between the different formations are visible along the shoreline of Bahía Cocinetas. Despite these stratigraphic relationships, this succession cannot be physically correlated with any particular beds in either the Jimol or Castilletes formations in the central and northern parts of the Cocinetas Basin. The lithofacies preserved in this succession includes fossiliferous conglomerate and coarse sands and distinct fossil assem- 
Table 2. Shark teeth specimens used in geochemical investigation.

\begin{tabular}{|c|c|c|c|c|c|}
\hline Sample ID & Taxon & Formation & Locality & $\delta^{18} \mathrm{O}_{\mathrm{PO}_{4}}(\%$, VSMOW $)$ & $\delta^{18} \mathrm{O}_{\mathrm{PO}_{4}} \mathrm{SD}$ \\
\hline HS.1 & $\dagger$ Hemipristis serra & Jimol & 290601 & 19.9 & 0.1 \\
\hline HS.2 & & & & 20.2 & 0.2 \\
\hline HS.3 & & Patsúa assemblage & 290472 & 20.1 & 0.1 \\
\hline HS.4 & & & & 20 & 0.1 \\
\hline HS.5 & & & & 20.6 & 0.1 \\
\hline CC.1 & $†$ Carcharocles chubutensis & & & 19.9 & 0.1 \\
\hline CC. 2 & & & & 19.1 & 0.2 \\
\hline CC. 3 & & & & 19.4 & 0.1 \\
\hline HS.6 & $\dagger$ Hemipristis serra & & 290468 & 19.3 & 0.1 \\
\hline HS.7 & & & & 20.2 & 0.3 \\
\hline HS. 8 & & & & 19.9 & 0.1 \\
\hline NG.1 & $\dagger$ Negaprion eurybathrodon & & & 18.9 & 0.2 \\
\hline NG.2 & & & & 19.9 & 0.2 \\
\hline GM.1 & $\dagger$ Galeocerdo mayumbensis & & & 20.5 & 0.1 \\
\hline GM.2 & & & & 20.3 & 0.1 \\
\hline GM.3 & & & & 19.3 & 0.2 \\
\hline SL.1 & $†$ Sphyrna laevissima & & & 19.9 & 0.0 \\
\hline SL. 2 & & & & 19.1 & 0.1 \\
\hline SL.3 & & & & 18.7 & 0.3 \\
\hline CC.4 & $†$ Carcharocles chubutensis & & & 17.4 & 0.3 \\
\hline CC. 5 & & & & 19.2 & 0.2 \\
\hline CC.6 & & & & 20.7 & 0.0 \\
\hline IO.1 & Isurus cf. I. oxyrinchus & & & 21.7 & 0.3 \\
\hline IO. 2 & & & & 20.8 & 0.0 \\
\hline IO.3 & & & & 19.3 & 0.3 \\
\hline PC.1 & $\dagger$ Physogaleus contortus & & & 19.8 & 0.0 \\
\hline PC. 2 & & & & 20.5 & 0.0 \\
\hline PC. 3 & & & & 19.4 & 0.1 \\
\hline HS.9 & $\dagger$ Hemipristis serra & Castilletes & 290632 & 19.8 & 0.3 \\
\hline HS. 10 & & & & 19.8 & 0.1 \\
\hline CS.1 & Carcharhinus sp. & & & 20.1 & 0.2 \\
\hline CS.2 & & & & 20.1 & 0.1 \\
\hline HS. 11 & $\dagger$ Hemipristis serra & & 290423 & 19.1 & 0.2 \\
\hline NG.3 & $\uparrow$ Negaprion eurybathrodon & & & 19.5 & 0.3 \\
\hline HS.12 & $\dagger$ Hemipristis serra & & 390090 & 19.6 & 0.0 \\
\hline HS. 13 & $\dagger$ Hemipristis serra & & & 19.5 & 0.0 \\
\hline NG.4 & $\dagger$ Negaprion eurybathrodon & & & 20.1 & 0.2 \\
\hline NG.5 & & & & 18.8 & 0.2 \\
\hline SA.1 & $\dagger$ Sphyrna arambourgi & & & 20.1 & 0.3 \\
\hline SA. 2 & & & & 19.2 & 0.1 \\
\hline HS.14 & $\dagger$ Hemipristis serra & & 430053 & 20.1 & 0.2 \\
\hline HS. 15 & & & & 20.4 & 0.0 \\
\hline NG.6 & $\dagger$ Negaprion eurybathrodon & & & 20.4 & 0.1 \\
\hline NG.7 & & & & 19.2 & 0.1 \\
\hline NG.8 & & & 130024 & 19.2 & 0.2 \\
\hline HS.16 & $\dagger$ Hemipristis serra & & 430202 & 21.1 & 0.0 \\
\hline HS.17 & & & & 19.7 & 0.1 \\
\hline NG.9 & $\dagger$ Negaprion eurybathrodon & & & 21.5 & 0.2 \\
\hline NG.10 & & & & 20.5 & 0.2 \\
\hline NG.11 & & & 290438 & 20.1 & 0.3 \\
\hline NG.12 & & & & 20.6 & 0.1 \\
\hline CS.3 & Carcharhinus sp. & & 290611 & 18.9 & 0.2 \\
\hline CS.4 & & & & 20.3 & 0.2 \\
\hline CS.5 & & & & 20.2 & 0.1 \\
\hline
\end{tabular}


Table 2. Continued.

\begin{tabular}{|c|c|c|c|c|c|}
\hline Sample ID & Taxon & Formation & Locality & $\delta^{18} \mathrm{O}_{\mathrm{PO}_{4}}(\%$, VSMOW $)$ & $\delta^{18} \mathrm{O}_{\mathrm{PO}_{4}} \mathrm{SD}$ \\
\hline HS.18 & $\dagger$ Hemipristis serra & Castilletes & 430101 & 19.8 & 0.1 \\
\hline NG.13 & $\dagger$ Negaprion eurybathrodon & & 390093 & 19.1 & 0.1 \\
\hline NG.14 & & & & 16.9 & 0.2 \\
\hline CS.6 & Carcharhinus sp. & & & 18.7 & 0.0 \\
\hline CS.7 & & & & 19.9 & 0.1 \\
\hline CL.1 & Carcharhinus leucas & Ware & 430059 & 18.1 & 0.1 \\
\hline CL.2 & & & & 18 & 0.1 \\
\hline CL.3 & & & 430052 & 18 & 0.1 \\
\hline CL.4 & & & & 18.4 & 0.0 \\
\hline CL.5 & & & 390083 & 18 & 0.1 \\
\hline CL.6 & & & & 18.9 & 0.0 \\
\hline CL.7 & & & 390080 & 18.6 & 0.1 \\
\hline CL.8 & & & & 15.7 & 0.2 \\
\hline CL.9 & & & 390077 & 15.7 & 0.2 \\
\hline CL.10 & & & & 18.3 & 0.0 \\
\hline CL.11 & & & 390075 & 16.4 & 0.3 \\
\hline CL.12 & Carcharhinus leucas & & & 17.2 & 0.2 \\
\hline NG.15 & $†$ Negaprion eurybathrodon & & & 20.7 & 0.1 \\
\hline NG.16 & & & & 20.5 & 0.0 \\
\hline
\end{tabular}

blages (Teredo-bored wood, an oceanic fauna of mollusks and echinoderms, and diverse elasmobranch and bony fish faunas) which are anomalous. For the purposes of analyzing the biodiversity and paleoecology of elasmobranch faunas in the Cocinetas Basin it is best to refer to these beds as the undifferentiated Jimol and Castilletes Formation. The underlying Siamana Formation may be as young as the Aquitanianearly Burdigalian (Silva-Tamayo et al., 2017), thereby constraining the maximum age of these beds as Burdigalian.

\subsection{Ware Formation (late Pliocene)}

The type section of the Ware Formation is located immediately east of the village of Castilletes, and correlated deposits are distributed along the eastern margin of the Cocinetas Basin (Fig. 1b), cropping out as conspicuous isolated hills with near-horizontal strata (Hendy et al., 2015; Moreno et al., 2015). The lithology of the Ware Formation is composed of light-gray mudstones, grayish-yellow fine sandstones, and muddy sandstones, reddish-gray pebbly conglomerates, yellowish-gray packstone biosparites and sandy to conglomeratic biosparites, with an estimated thickness of approximately $52 \mathrm{~m}$. The lower contact is unconformable with the underlying Castilletes Formation, and the upper contact is a fossiliferous packstone in the stratotype that marks the youngest preserved Neogene sedimentation in the Cocinetas Basin (Moreno et al., 2015; Pérez-Consuegra et al., 2018). The basal section of the unit was deposited in a fluvio-deltaic environment, and abundant plant and vertebrate remains (including sharks referred to herein, fishes, turtles, crocodilians and mammals) have been found in the conglomeratic layers (Moreno et al., 2015; Amson et al., 2016; Moreno-
Bernal et al., 2016; Pérez et al., 2016). Only marine invertebrates have been found in the top beds of the Ware Formation (e.g., Hendy et al., 2015), suggesting an exposed openocean shoreface and nearshore settings including coral reefs (Moreno et al., 2015). A late Pliocene (Piacenzian) range of 3.40 to $2.78 \mathrm{Ma}$ age is assigned to the Ware Formation on the basis of macroinvertebrate biostratigraphy and ${ }^{87} \mathrm{Sr} /{ }^{86} \mathrm{Sr}$ isotope chronostratigraphy (Moreno et al., 2015).

\section{Results}

\subsection{Elasmobranch paleodiversity}

The taxonomic composition of the 36 fossiliferous localities (Table S1) includes at least 30 taxa of squalomorphs, galeomorphs and batoids (Table 1, Figs. 3-8). Squalomorphs are represented by two species, two genera, and two families of Squaliformes and Pristiophoriformes. Galeomorphs are represented by at least 20 species, 13 genera and seven families of Orectolobiformes, Lamniformes and Carcharhiniformes (Table 1). Batoids include seven species, seven genera and seven families of Rhinopristiformes and Myliobatiformes (Table 1).

- Squaliformes Goodrich, 1909. This group (Table 1) is represented by two specimens referable to Dalatias cf. D. licha (Bonnaterre, 1788) (Fig. 3a-d, Table S2) from the Jimol Formation (Table S1). This taxon was previously identified in the Cocinetas Basin (Uitpa Formation) by Carrillo-Briceño et al. (2016b). 


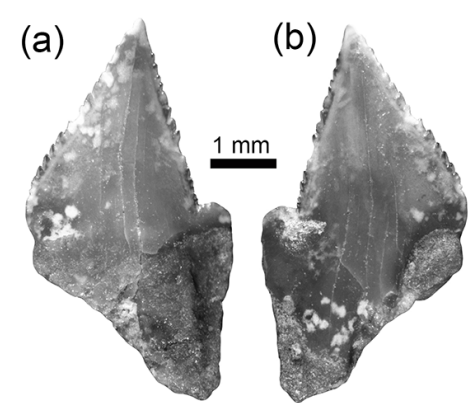

(h)
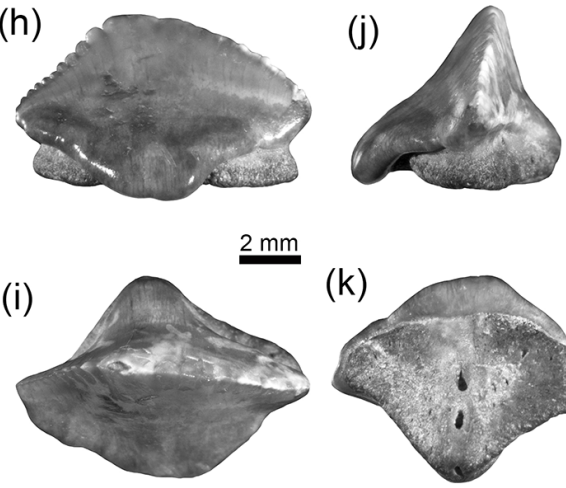

(k)

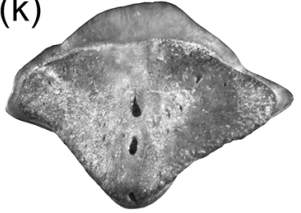

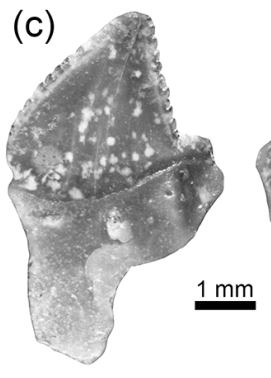

(I)

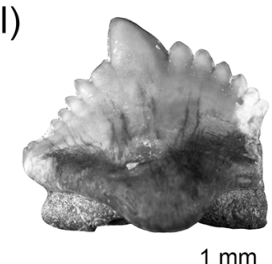

$(\mathrm{m})$

$1 \mathrm{~mm}$

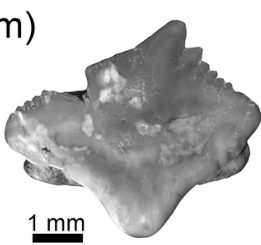

(w)

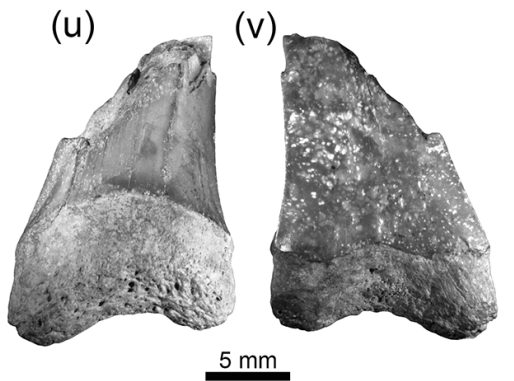

(d)

(e)

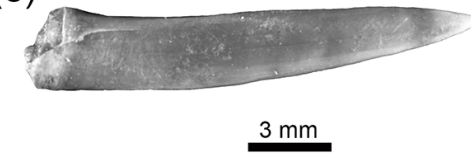

(f)

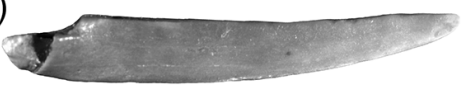

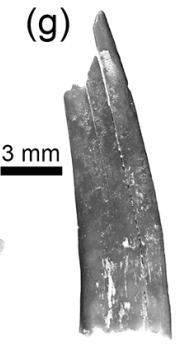

(q)

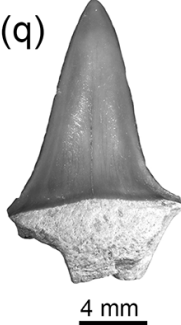

(n)

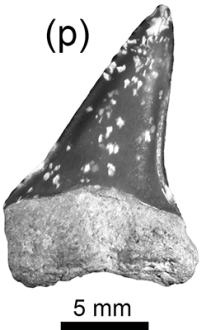

$2 \mathrm{~mm}$
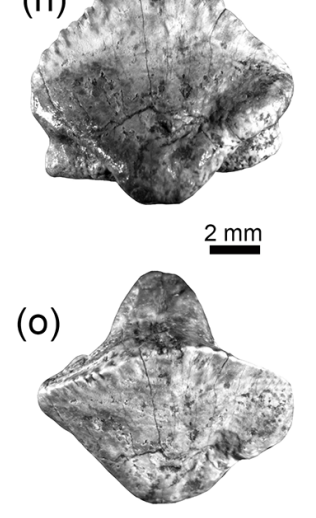
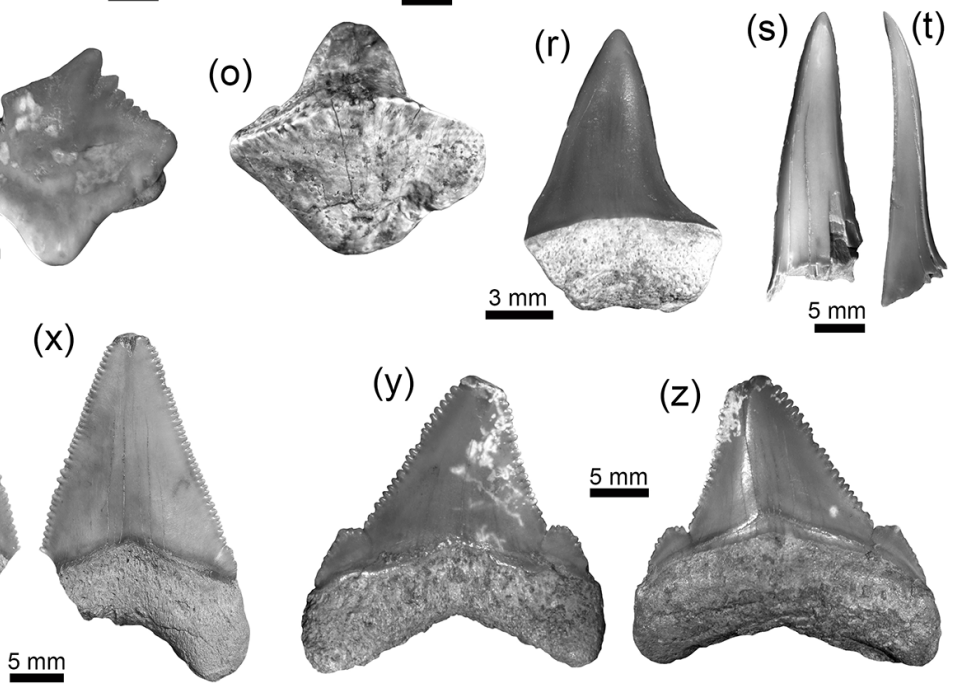

(z)

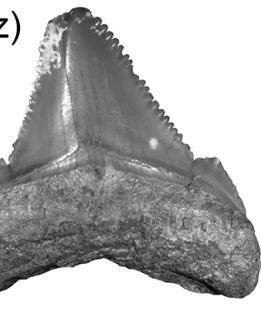

Figure 3. Squaliformes, Pristiophoriformes, Orectolobiformes and Lamniformes of the Cocinetas Basin. (a-d) Dalatias cf. D. licha (MUNSTRI-41205). (e-g) Pristiophorus sp. (MUN-STRI-34788). (h-o) Nebrius sp. (h-m: MUN-STRI-41136; n-o: MUN-STRI-41180). (pt) Isurus cf. I. oxyrinchus (MUN-STRI-37671). (u-v) †Parotodus benedenii (MUN-STRI-43742). (w-z) $\dagger$ Carcharocles chubutensis (MUNSTRI-40375). Jaw position: upper (y-z?), lower $(\mathbf{a}-\mathbf{d}, \mathbf{w}-\mathbf{x})$ and indeterminate $(\mathbf{h}-\mathbf{v})$, as well as rostral (e-g). The question marks in labels are for when we were uncertain if the referred to tooth is from its assigned position in the jaw (upper, lower, etc.). View: labial (b, $\mathbf{d}, \mathbf{h}, \mathbf{l}$, $\mathbf{n}-\mathbf{o}, \mathbf{v}, \mathbf{x}-\mathbf{y})$, lingual $(\mathbf{a}, \mathbf{c}, \mathbf{p}-\mathbf{s}, \mathbf{u}, \mathbf{w}, \mathbf{z})$, profile $(\mathbf{j}, \mathbf{t})$, occlusal $(\mathbf{i}, \mathbf{m})$, dorsal $(\mathbf{e}-\mathbf{g})$ and basal (k). Geological unit: Jimol Formation (a-d), Castilletes Formation (h-o) and Patsúa assemblage - locality 290468 (e-g, p-z).

- Pristiophoriformes Berg, 1958. Five isolated crowns of rostral teeth of Pristiophorus indet. Müller and Henle, 1837 (Fig. 3e-g, Tables 1, S2) were collected in the Patsúa Valley from the locality 290468 (Table S1). Similar specimens were recorded from the Uitpa Formation by Carrillo-Briceño et al. (2016b).

- Orectolobiformes Applegate, 1972. Eight specimens referable to an indeterminate species of Nebrius Rüppell, 1837 (Fig. 3h-o, Tables 1, S2) were collected exclusively from Burdigalian localities of the Castilletes
Formation (Table S1). The specimens are morphologically similar to those of Nebrius sp. reported from the Cantaure Formation (Burdigalian) in the Falcon Basin, Venezuela and Pirabas Formation (AquitanianBurdigalian), Brazil (Aguilera et al., 2017a). For summarized information about taxonomy and the stratigraphic range of Nebrius in the Americas see CarrilloBriceño et al. (2016a, p. 6).

- Lamniformes Berg, 1937. These sharks represent the second most diverse group from the Cocinetas elasmo- 

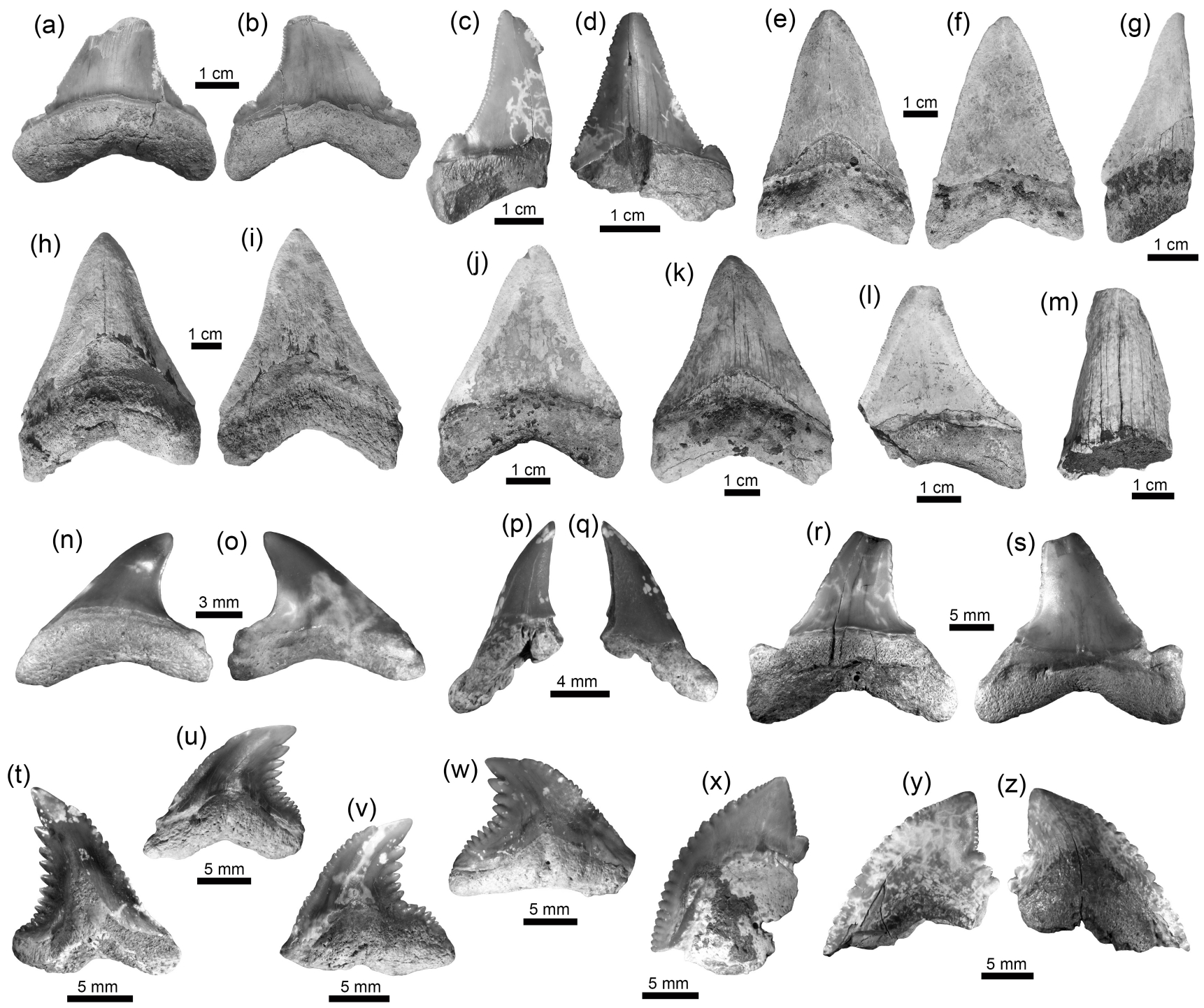

Figure 4. Lamniformes and Carcharhiniformes of the Cocinetas Basin. (a-d) †Carcharocles chubutensis (MUN-STRI-40375). (el) †Carcharocles megalodon (e-g: MUN-STRI-37812; h-i: MUN-STRI-38067; j-l: MUN-STRI-41145). (m) †Carcharocles sp. (MUNSTRI- 41138). (n-q) Alopias cf. A. exigua (MUN-STRI-43745). (r-s) †Anotodus retroflexus (MUN-STRI-43740). (t-w) †Hemipristis serra (MUN-STRI-34790). (x-z) †Galeocerdo mayumbensis (x: MUN-STRI-41135; y-z: MUN-STRI-40377). Jaw position: upper (j-l, n, u-w), lower (a-b?, c-f, h-i?, p-q?, t) and indeterminate (g, $\mathbf{m}, \mathbf{r}-\mathbf{s}, \mathbf{x}-\mathbf{z})$. View: labial $(\mathbf{b}-\mathbf{c}, \mathbf{f}, \mathbf{i}-\mathbf{j}, \mathbf{l}, \mathbf{o}, \mathbf{q}, \mathbf{s}, \mathbf{y})$ and lingual (a, d-e, g-h, $\mathbf{k}, \mathbf{m}-\mathbf{n}, \mathbf{p}$, $\mathbf{r}, \mathbf{t}-\mathbf{x}, \mathbf{z})$. Geological unit: Jimol Formation (m), Castilletes Formation (e-l, x) and Patsúa assemblage - locality 290468 (a-d, n-w, y-z).

branch assemblages (Fig. 9a), with records for the Jimol and Castilletes formations and Patsúa assemblage (locality 290468) (Fig. 9b, Tables S1-S2). Isurus cf. I. oxyrinchus Rafinesque, 1810 (Fig. 3p-t), †Parotodus benedenii (Le Hon, 1871) (Fig. 3u-v), †Carcharocles chubutensis (Ameghino, 1901) (Figs. 3w-z, 4a-d), Alopias cf. $\dagger$ A. exigua (Probst, 1879) (Fig. 4n-q) and $\dagger$ Anotodus retroflexus (Agassiz, 1843) (Fig. 4r-s) are recorded exclusively at locality 290468 (Table S1), whereas Carcharocles sp. (Fig. $4 \mathrm{~m}$ ) occurs in the Jimol Formation and $\dagger$ Carcharocles megalodon (Agassiz, 1843) (Fig. 4e-1) in only three localities of the late Bur- digalian strata of the Castilletes Formation (Table S1) $\dagger$ Carcharocles chubutensis and $\dagger C$. megalodon are the most abundant lamniforms from all studied localities of the Cocinetas Basin (Table S1). Due to the relatively small size of the $\dagger C$. chubutensis teeth from the localities 290468 and 290472 (Table S1), these likely belong to juvenile individuals (Figs. $3 \mathrm{w}-\mathrm{z}, 4 \mathrm{a}-\mathrm{d}$ ).

- Carcharhiniformes Berg, 1937. With 14 taxa this is the most diverse and the second most abundant elasmobranch group from the Cocinetas assemblages (Fig. 9a). The Carcharhinidae Jordan and Evermann, 

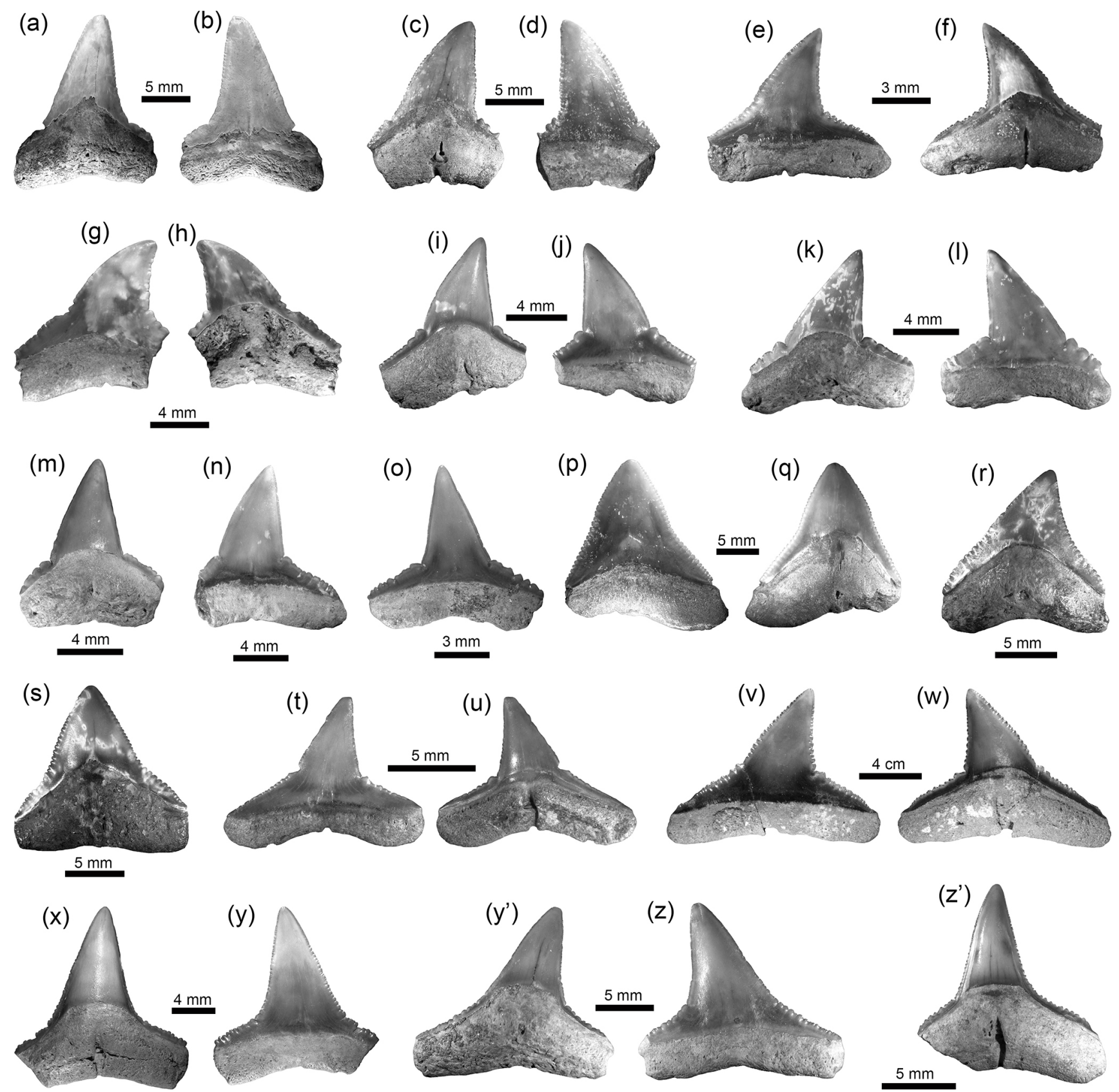

Figure 5. Carcharhiniformes of the Cocinetas Basin. (a-d) †Carcharhinus ackermannii (a-b: MUN-STRI-41128; c-d: MUN-STRI-43743). (e-h) Carcharhinus cf. C. brachyurus (MUN-STRI-41207). (i-o) †Carcharhinus gibbesii (MUN-STRI-43808). (p-s) Carcharhinus leucas (p-q: MUN-STRI-37646; r: MUN-STRI-21937; s: MUN-STRI-16287). (t-u) Carcharhinus cf. C. limbatus (MUN-STRI-41153). (v-w) Carcharhinus cf. C. perezi (MUN-STRI-41129). (x-z') Carcharhinus cf. $\dagger$ C. priscus (MUN-STRI-43804). Jaw position: upper (a-z'). View: labial (b, d-e, g, j, l, n-p, t, v, y, z) and lingual (a, c, f, h-i, k, m, q-s, u, w-x, y', z'). Geological unit: Jimol Formation (a-b, e-h, t-w), Castilletes Formation (t-u), Ware Formation (p-s) and Patsúa assemblage - locality 290468 (c-d, i-o, x-z').

1896 is the most diverse family represented in the Cocinetas assemblages (Fig. S5), with five genera and 11 species: $\dagger$ Galeocerdo mayumbensis Dartevelle and Casier, 1943 (Fig. 4x-z); †Carcharhinus ackermannii Santos and Travassos, 1960 (Fig. 5a-d); Carcharhinus cf. C. brachyurus (Günther, 1870) (Fig. 5e-h); $\dagger$ Carcharhinus gibbesii (Woodward, 1889) (Fig. 5ko); Carcharhinus leucas (Müller and Henle, 1839) (Fig. 5p-s); Carcharhinus cf. C. limbatus (Müller and Henle, 1839) (Fig. 5t-u); Carcharhinus cf. C. perezi (Poey, 1876) (Fig. 5v-w); Carcharhinus cf. $\dagger$. priscus (Agassiz, 1843) (Figs. 5x-z', 6a-d); †Isogomphodon 
acuarius (Probst, 1879) (Fig. 6h-i); †Negaprion eurybathrodon (Blake, 1862) (Fig. 6j-n); and $†$ Physogaleus contortus (Gibbes, 1849) (Fig. 6o-r). Other less diverse groups of carcharhiniforms are represented by the Sphyrnidae Gill, 1872 - †Sphyrna arambourgi Cappetta, 1970 (Fig. 6s-v); †Sphyrna laevissima (Cope, 1867) (Fig. 6w-z') - and the Hemigaleidae Hasse, 1879 - †Hemipristis serra (Agassiz, 1835) (Fig. 4tw) - with the latter being the most abundant taxon among the studied carcharhiniforms (Tables S1-S2). From the above-mentioned taxa from the Cocinetas Basin, only $\dagger N$. eurybathrodon shows a record from the early Miocene to the late Pliocene. Although taxonomic discussions are out of the scope of this contribution, teeth of $\dagger N$. eurybathrodon are indistinguishable from the extant species Negaprion brevirostris (Poey, 1868), which also has been noted in the fossil record of the Americas (see Carrillo-Briceño et al., 2015a, Table 2; 2016b, Table 2). As there is no detailed revision supporting or rejecting the above assumption, just as Carrillo-Briceño et al. (2016a), we use $\dagger N$. eurybathrodon (for fossil specimens), sustained by the principle of priority of the International Code of Zoological Nomenclature. In reference to the Carcharhinus spp. teeth (Fig. 6e-g), we have referred all specimens that are broken, eroded and without any diagnostic features for specific identification.

- Rhinopristiformes Last, Séret and Naylor, 2016. Two taxa of this group of batoids are represented in the Cocinetas assemblages (Fig. 9, Table 1, Fig. S5). Rhynchobatus Müller and Henle, 1837 was recovered from the Castilletes Formation and is represented by a few isolated teeth (Fig. 7a-i, Table S1). Our Rhynchobatus sp. specimens resemble those from the Neogene of Venezuela and other locations in tropical America (Carrillo-Briceño et al., 2016a; Aguilera et al., 2017a). We refrain from taxonomic identification at the species level of our specimens because the range of dental variation in extant species is unknown, and little is known about fossil species from the Americas (CarrilloBriceño et al., 2016a). Pristis Linck, 1790 is present in both the Castilletes and Ware formations and represented by rostral denticles and a fragment of rostrum (Fig. 7j-m, Table S1). Noted by Carrillo-Briceño et al. (2015b), rostral fragments and denticles are not diagnostic for accurate specific taxonomic determinations.

- Myliobatiformes Compagno, 1973. This order is represented by five taxa: $\dagger$ Plinthicus stenodon Cope, 1869 (Fig. 8u-x); indeterminate teeth of Dasyatis Rafinesque, 1810 (Fig. 7n-u); Aetobatus Blainville, 1816 (Fig. 7v-x); Aetomylaeus Garman, 1913 (Fig. 8aj); and Rhinoptera Cuvier, 1829 (Fig. 8k-t). This group of batoids (Table 1) is the most abundant and the third most diverse group of chondrichthyans in the Cocinetas assemblages (Fig. 9, Tables S1-S2, Fig. S5). Teeth assigned to Aetobatus sp., $\dagger P$. stenodon and Dasyatis sp. are scarce and only found in the Castilletes Formation and Patsúa assemblage (locality 290468) (Table S1). Aetomylaeus sp. is reported only in the $\mathrm{Ji}$ mol and Castilletes formations and the locality 290468, whereas Rhinoptera sp. has a record in the Cocinetas assemblages from the early Miocene to the late Pliocene and is the most abundant taxon (Tables S1-S2). More than 419 highly eroded and broken teeth without any diagnostic features for generic determination have been assigned to Myliobatoidea indet. (Table S1); however, they could belong to Aetomylaeus or Rhinoptera.

\subsection{Dietary preferences}

Although extant representatives of the fossil elasmobranchs present in the Cocinetas assemblage exhibit a wide range of diets, four feeding preferences of benthic-pelagic predators and filter feeders can be recognized (Table S3). For the Jimol Formation, piscivorous feeders are the most diverse group (Fig. 10), which is dominated by carcharhiniforms, lamniforms and a few squaliforms (Table S3). The second most diverse group is durophagous/cancritrophic (mollusk, crustacean, coral feeders), which is the most abundant in the Jimol assemblages (Fig. 10) and dominated mainly by myliobatiform taxa (Table S3). $†$ Carcharocles sp. is the only possible eurytrophic/sarcophagous (diverse prey sources: fishes, reptiles, birds, mammals, etc.) representative of this unit. Like the Jimol Formation, the Castilletes Formation fauna also shows a diversity dominated by piscivorous taxa (Fig. 10) and an abundance dominated by the durophagous/cancritrophic group (represented in the Castilletes assemblage mainly by myliobatiforms) (Table S3). In the Castilletes assemblage, $†$ Carcharocles megalodon and $\dagger$ Galeocerdo mayumbensis are the only representatives of the eurytrophic/sarcophagous feeding niche, and the filterfeeding niche (diet based mainly on planktonic microorganisms) is represented only by the mobulid $\dagger$ Plinthicus stenodon (Fig. 10, Table S3). In contrast, the Patsúa assemblage (localities 290468 and 290472) is characterized by a higher diversity and abundance of piscivores, followed by durophagous/cancritrophic diets (Fig. 10, Table S3). Eurytrophic/sarcophagous and filter feeders also are represented in the localities 290468 and 290472 (Fig. 10, Table S3). In contrast with the Jimol, Castilletes and Patsúa assemblages, the elasmobranch assemblage from the Ware Formation shows low diversity and abundance of taxa (Fig. 10, Tables S1-S3).

\subsection{Stable isotope analysis of shark teeth}

The $\delta^{18} \mathrm{O}_{\mathrm{PO}_{4}}$ values of 73 shark teeth analyzed have a range from $15.7 \%$ to $21.7 \%$ (VSMOW, Table 2). Samples were 

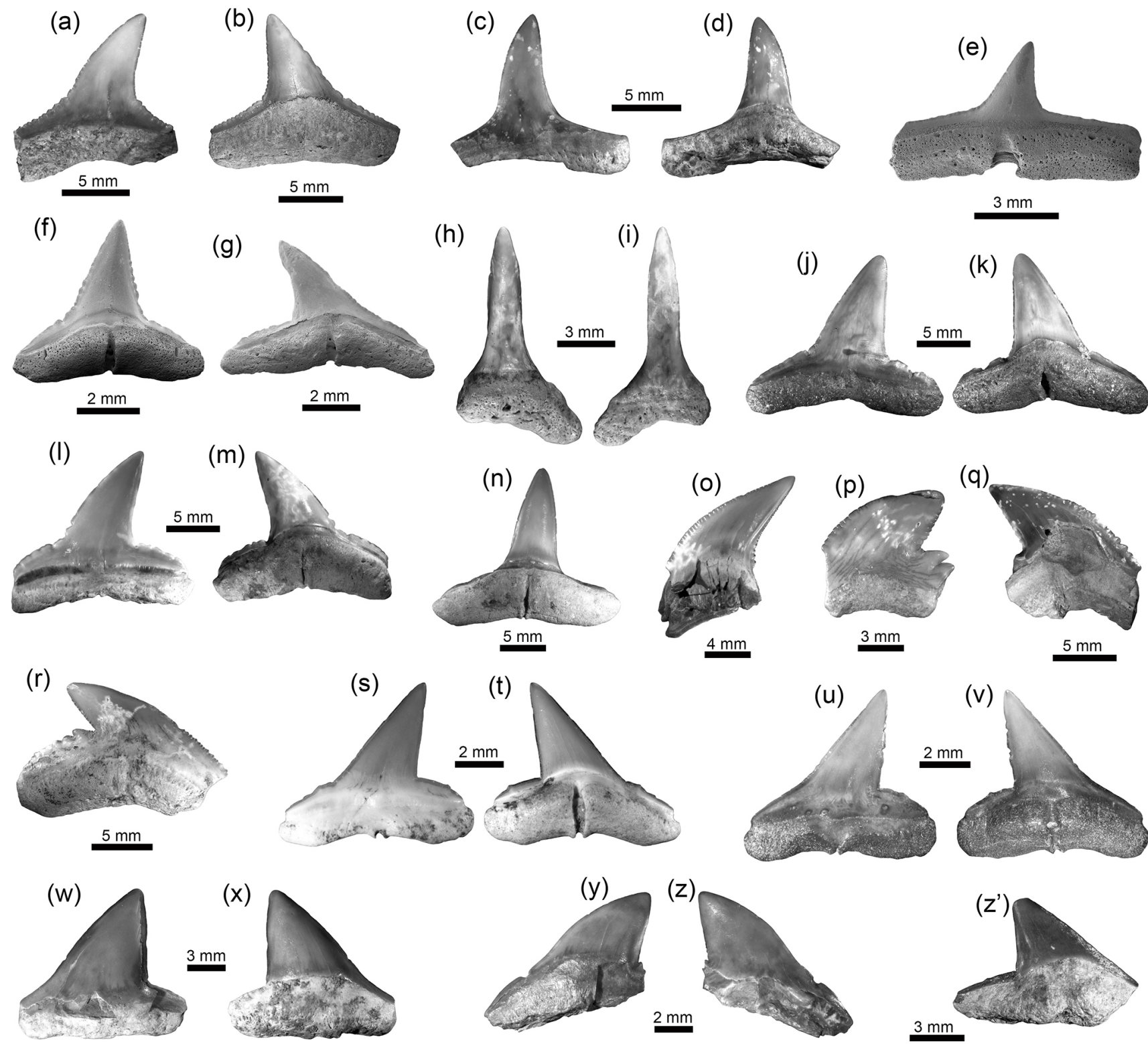

Figure 6. Carcharhiniformes of the Cocinetas Basin. (a-d) Carcharhinus cf. $\dagger$ C priscus (MUN-STRI-43804). (e-g) Carcharhinus spp. (e: MUN-STRI-42136; f-g: MUN-STRI-42128). (h-i) †Isogomphodon acuarius (MUN-STRI-41184). (j-n) †Negaprion eurybathrodon (MUN-STRI-41133). (o-r) †Physogaleus contortus (o-q: MUN-STRI-40378; r: MUN-STRI-41132). (s-v) †Sphyrna arambourgi (MUNSTRI-41143). (w-z') †Sphyrna laevissima (MUN-STRI-43741). Jaw position: upper (a-b, f-g, j-m, s-z, z’?), lower (c-e, h-i, n) and indeterminate (o-r). View: labial (a, c, e, i-j, l, p, s, u, w, z) and lingual (b, d, f-h, k, m-o, q-r, t, v, x-y, z'). Geological unit: Castilletes Formation (e-n, r-v) and Patsúa assemblage - locality 290468 (a-d, o-q, w-z').

grouped in accordance with their geochronological position in the stratigraphic column (Fig. 11). Adjacent layers were averaged to be representative for a wider period. The range of the $\delta^{18} \mathrm{O}_{\mathrm{PO}_{4}}$ values within the same beds varies up to $4 \% o$ and the highest is in the Patsúa assemblage (locality 290468), where many teeth from different species were available (seven species, $n=26$ ).

Results from sharks of the Patsúa assemblage are mainly discussed in terms of paleoecology, since the age of the assemblage is unknown. The average isotope compositions from the two stratigraphically uncertain Patsúa layers are very similar (localities 290468 and 290472; $t$ test: $t(24)=$ $0.275 ; p>0.78$ ) and hence can be considered as one data set.

In the Castilletes Formation, the mean $\delta^{18} \mathrm{O}_{\mathrm{PO}_{4}}$ values do differ along the stratigraphic column (Fig. 11a). Statistical tests performed in stratigraphic orders have not shown significant differences between the sample batches that are fol- 
(a)

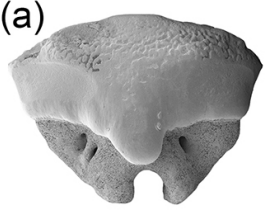

(b)

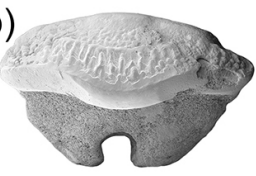

(c)

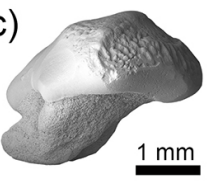

(d)

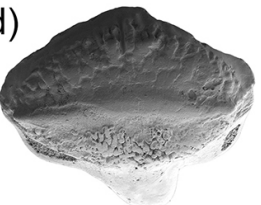

(e)

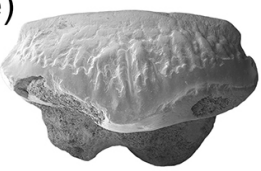

(f)

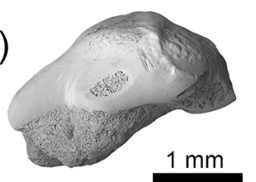

(g)

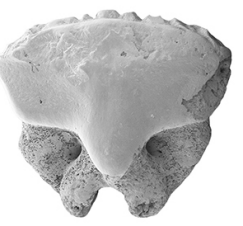

(h)

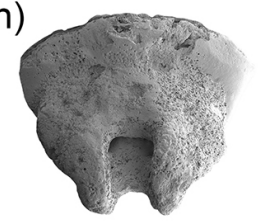

(i)

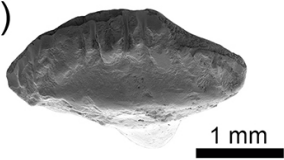

(j)

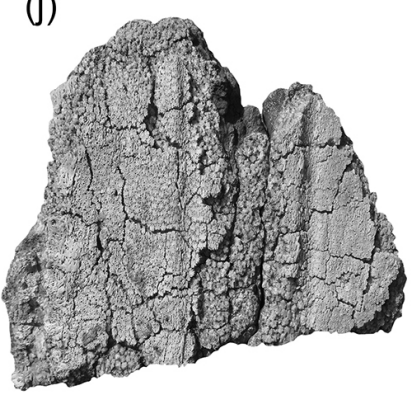

(k)

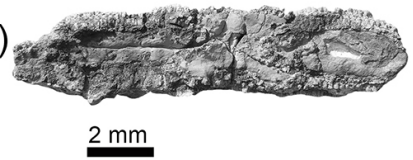

(I)

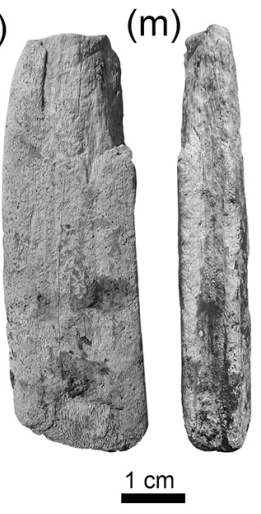

(n)

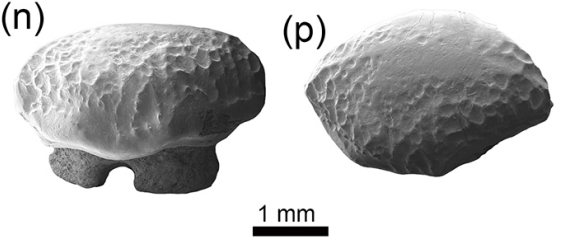

(o)

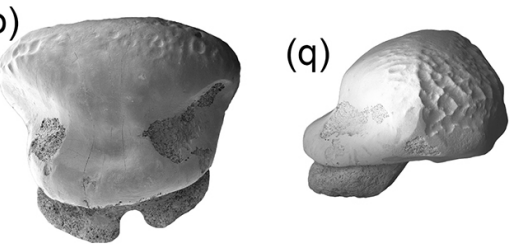

(r)

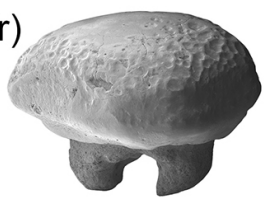

(s)

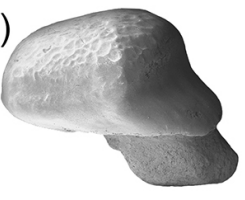

$(\mathrm{t})$

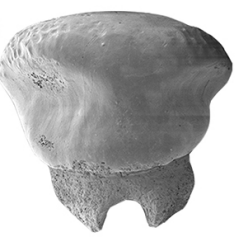

(u)

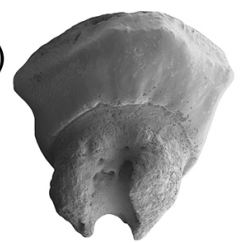

(v)

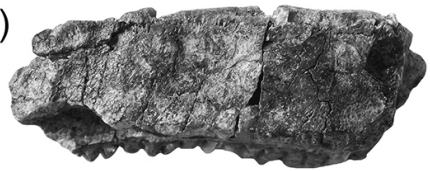

(w)

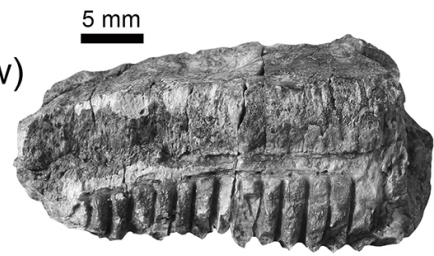

(x)

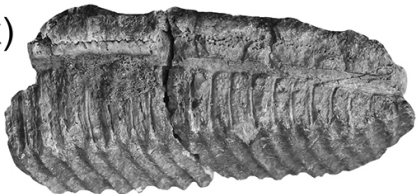

Figure 7. Rhinopristiformes and Myliobatiformes of the Cocinetas Basin. (a-i) Rhynchobatus sp. (MUN-STRI- 42132). (j-m) Pristis sp. (fragment of rostrum j-k: MUN-STRI-37397; rostral denticle l-m: MUN-STRI-34762). (n-u) Dasyatis sp. (MUN-STRI-42135). (v-x) Aetobatus sp. (MUN-STRI-34465). Jaw position: indeterminate (a-i, n-x). View: labial (b, e, n, r, x), lingual (a, g, o, t, w), profile (c, f, q, $\mathbf{s})$, occlusal (d, i, p, v), dorsal (j, l), posterior (k), basal (h, u). Geological unit: Castilletes Formation (a-x).

lowing each other, except for the uppermost locality 390093. Tukey's pairwise comparison distinguished the top bed as different from the two lower levels of 290438 and 430202 130024. Samples from this layer had the lowest average $\delta^{18} \mathrm{O}_{\mathrm{PO}_{4}}$ value for this lithostratigraphic unit $(18.7 \pm 1.3 \%$, $n=4)$.

In the youngest unit of the Ware Formation, low ${ }^{18} \mathrm{O} /{ }^{16} \mathrm{O}$ values were measured for the bull shark $C$. leucas specimens (CL.1-CL.12: $17.6 \pm 1.1 \%$, $n=12$, Fig. 11a). Interestingly, when the average data of the Ware beds are compared to the youngest bed of the Castilletes Formation they do not show significant differences ( $t$ test: $t(16)=0.748, p>0.46$ ).

From the older Jimol Formation only two teeth were analyzed, but their average is indistinguishable from that of the overall average value of both the Castilletes and Patsúa assemblages. When the Patsúa, Castilletes and Ware assemblages are compared on a box plot, the averages of the first two are indistinguishable (Fig. 11b). However, both are dif- ferent from the Ware samples. Outliers toward lower isotopic values were found in the Patsúa and Castilletes faunas, which are $\dagger$ Carcharocles chubutensis (290468) and $\dagger$ Negaprion eurybathrodon (390093) specimens, respectively.

\section{Discussion}

\subsection{Diversity and biostratigraphy significance}

Of the elasmobranch assemblages described here from the Cocinetas Basin ( 30 taxa) at least half of the fauna is characterized by extinct taxa (Table 1). With the exception of Alopias cf. $\dagger$ A. exigua (Fig. 4n-q, Tables S1-S2), representing the first record of this taxon from tropical America, the remaining taxa from the Cocinetas assemblages have been found in other Neogene deposits of the Americas (e.g., Kruckow and Thies, 1990; Purdy et al., 2001; Aguilera and Lundberg, 2010; Cappetta, 2012; Carrillo-Briceño 
(a)

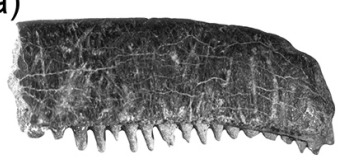

(b)

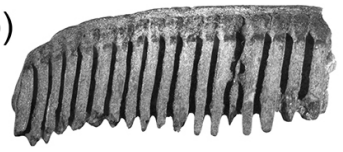

(c)

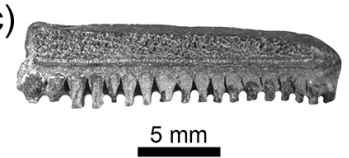

(0)

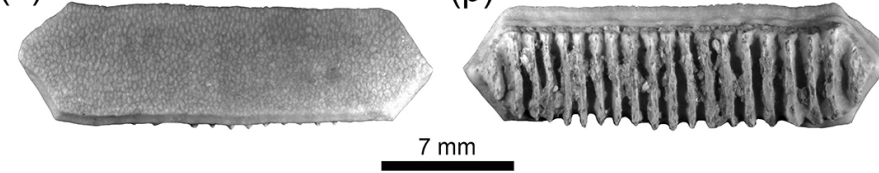

(p)

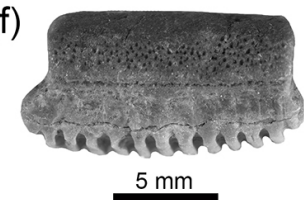

(e)

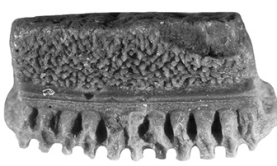

(f)
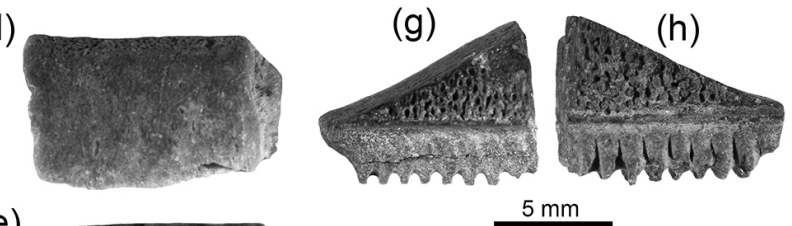

(k)

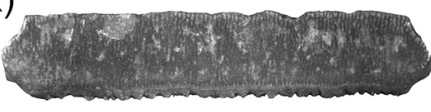

(I)

(i)

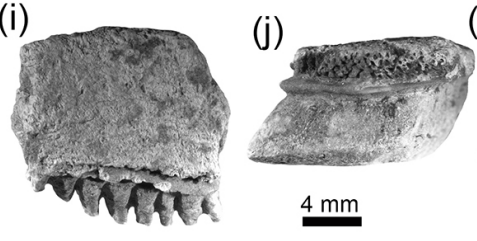

(q)

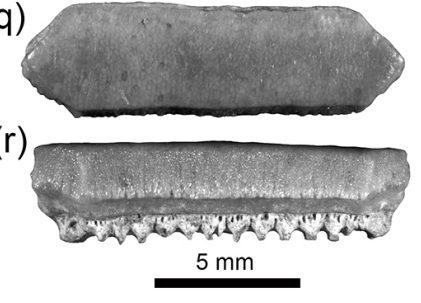

(u)

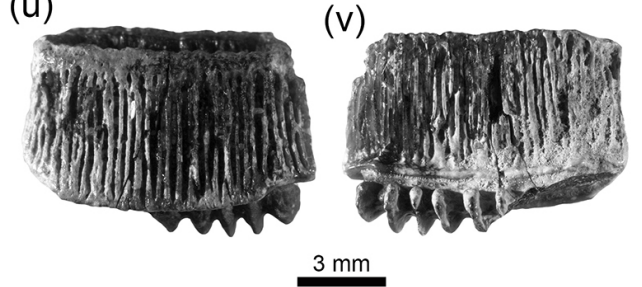

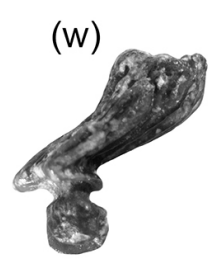

(r)

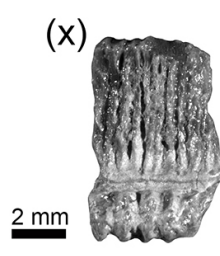

(y)

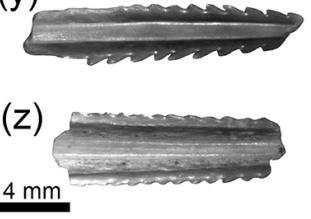

(s)

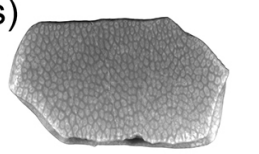

(t)
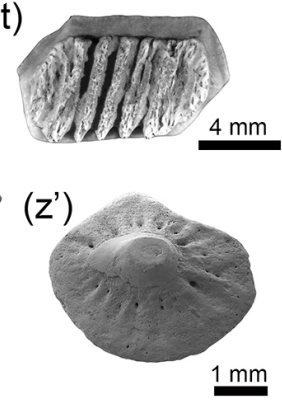

Figure 8. Myliobatiformes of the Cocinetas Basin. (a-j) Aetomylaeus sp. (a-c: MUN-STRI-41134; d-f: MUN-STRI-43746; g-j: MUNSTRI-41134). (k-t) Rhinoptera sp. (MUN-STRI-41138). (u-x) †Plinthicus stenodon (MUN-STRI-41203). (y-z') Myliobatiformes indet. (caudal spines y-z: MUN-STRI-34785; denticle z': MUN-STRI-42134). Jaw position: indeterminate (a-x). View: labial (f, g, n, r, u), lingual (c, e, h, m, v, x), profile (j, w), occlusal $(\mathbf{a}, \mathbf{d}, \mathbf{i}, \mathbf{k}, \mathbf{o}, \mathbf{q}, \mathbf{s})$, ventral $(\mathbf{y}-\mathbf{z})$, basal $(\mathbf{b}, \mathbf{l}, \mathbf{p}, \mathbf{t})$. Geological unit: Castilletes Formation (a-c, $\left.\mathbf{g}-\mathbf{x}, \mathbf{z}^{\prime}\right)$, Ware Formation (y-z) and Patsúa assemblage - locality 290468 (d-f).

et al., 2014, 2015b, 2016a; Landini et al., 2017, and references therein). From the Cocinetas assemblages, 17 shark taxa (Nebrius sp., $\dagger P$. benedenii, $\dagger C$. chubutensis, $\dagger C$. megalodon, Alopias cf. $\dagger$ A. exigua, $\dagger A$. retroflexus, $\dagger G$. mayumbensis, $\dagger C$. ackermannii, Carcharhinus cf. C. brachyurus, $C$. leucas, Carcharhinus cf. C. limbatus, Carcharhinus cf. $C$. perezi, Carcharhinus cf. $\dagger$ C. priscus, $\dagger$ I. acuarius, $\dagger N$. eurybathrodon, $\dagger P$. contortus and $\dagger S$. arambourgi) and seven batoids (Rhynchobatus sp., Pristis sp., Dasyatis sp., Aetobatus sp., Aetomylaeus sp., Rhinoptera sp. and $\dagger$ P. stenodon) are reported for the first time from Colombian Neogene deposits. The elasmobranch assemblages of the Jimol and Castilletes formations and the Patsúa assemblage share certain similarities with the fauna previously described from the underlying Uitpa Formation (e.g., Carrillo-Briceño et al., 2016b).

The elasmobranch fauna of the Cocinetas assemblages shows a clear differentiation in paleodiversity between geological units (see Fig. S5). The Castilletes Formation and Patsúa assemblage are the most diverse units of all the assem- blages from the Cocinetas Basin (Tables S1-S2, Fig. S5). In contrast, the Jimol and Ware formations are the least diverse units (Tables S1-S2, Fig. S5). These paleodiversity differences between the geological units of the Cocinetas Basin could be attributed to (1) less intensive sampling, especially less systematic sieving of all studied localities (see Sect. 2); and/or (2) different lithologic, taphonomic and preservational conditions, without dismissing a direct response to the paleoenvironmental and paleoecological conditions (see the below Sect. 5.2). The Castilletes Formation and Patsúa assemblage preserve one of the most diverse elasmobranch faunas known from the early-middle Miocene of the Americas (Fig. S6).

Of biostratigraphic significance to the elasmobranch fauna of the Cocinetas assemblages is the record of $\dagger C$. megalodon, $\dagger G$. mayumbensis, $\dagger C$. gibbesii and $\dagger C$. ackermannii. The presence of $\dagger C$. megalodon in late Burdigalian sediments of the Castilletes Formation (localities 130024, 290824 and 430202, Fig. 2b) confirms the presence of this species dur- 
(a)

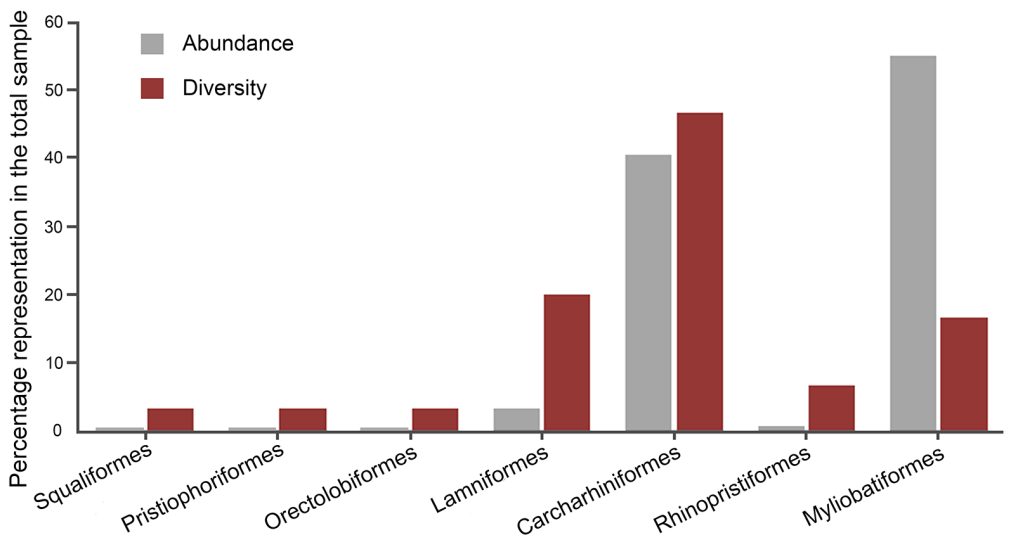

(b)

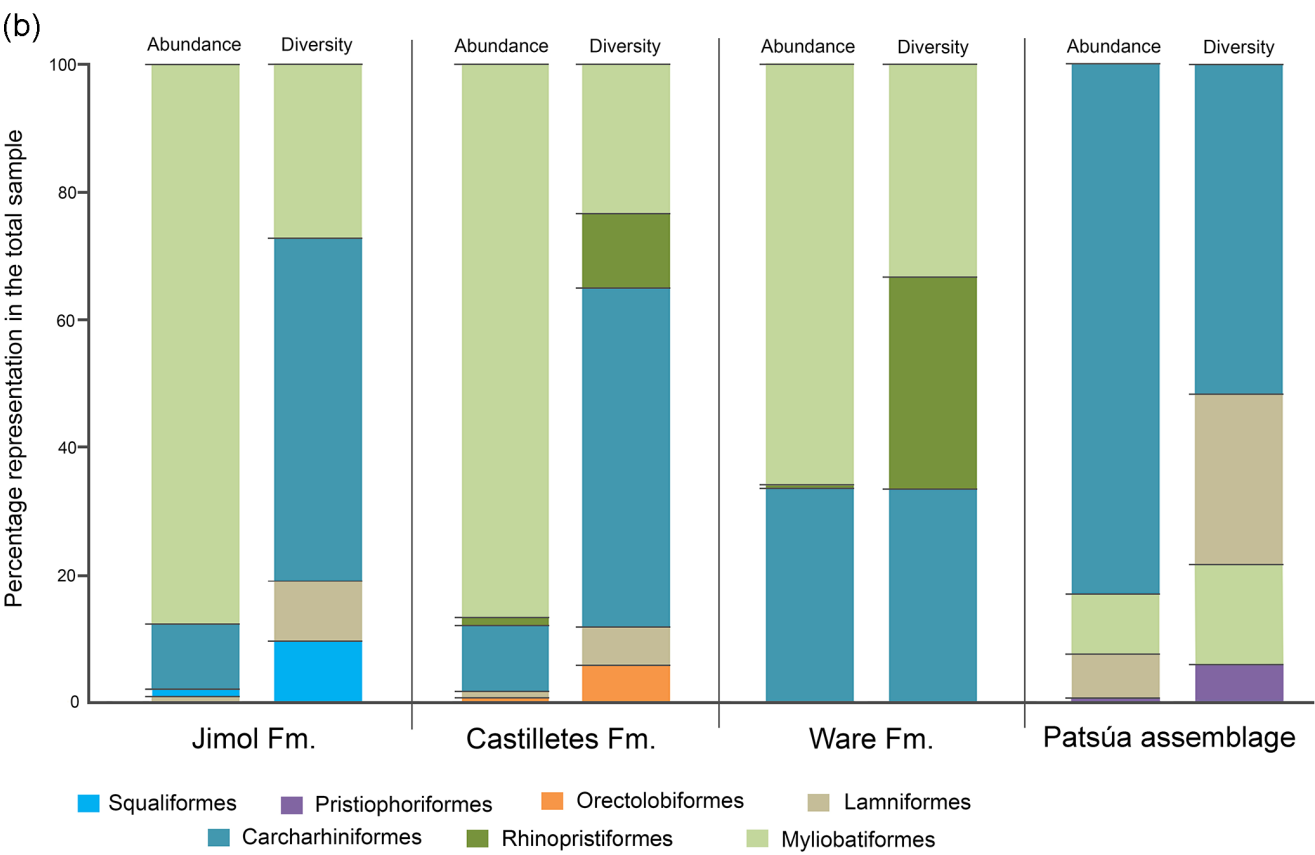

Figure 9. Elasmobranch paleodiversity (orders) of the Cocinetas Basin. (a) Overall assemblages. (b) Assemblages by geological units.

ing late early Miocene, an assertion that has been previously discussed for other American localities by Carrillo-Briceño et al. (2016a, p. 21, and references therein). The ages of the above-mentioned localities of the Castilletes Formation have been estimated by ${ }^{87} \mathrm{Sr} /{ }^{86} \mathrm{Sr}$ isotope stratigraphy (Hendy et al., 2015, Fig. 16, Table 6). In the case of $† C$. chubutensis, this species is restricted to the Patsúa assemblage, which suggests that the previous specimens of $\dagger$ Carcharocles sp. referred to the Uitpa Formation by Carrillo-Briceño et al. (2016b, Fig. 4.12-13) could belong to the former species. Due to the relatively small size of the $† C$. chubutensis teeth from the localities 290468 and 290472 (Table S1), these likely belong to juvenile and subadults individuals (Figs. $3 \mathrm{w}-$ $\mathrm{z}, 4 \mathrm{a}-\mathrm{d})$. The specimens assigned here to $\dagger C$. chubutensis are characterized by the presence of a pair of lateral cusplets that are not separated from the main cusp and a narrower cusp in the lower teeth, while those assigned to $† C$. megalodon have a wider crown in the lower teeth and lack lateral cusplets.

$\dagger$ Carcharhinus gibbesii in the Jimol Formation, besides being present in the Patsúa assemblage, is also present in the Burdigalian sediments of the Cantaure Formation in Venezuela (Carrillo-Briceño et al., 2016a). These records from the late part of the early Miocene are notable as the last appearance of $\dagger C$. gibbesii has been regarded as Aquitanian (Carrillo-Briceño et al., 2016b). †Carcharhinus ackermannii is reported here from the Burdigalian sediments of the Castilletes Formation and Patsúa assemblage (Tables S1S2). However, it has been exclusively reported previously from the early Miocene Cantaure (Venezuela) and Pirabas (Brazil) formations (Santos and Travassos, 1960; Carrillo- 


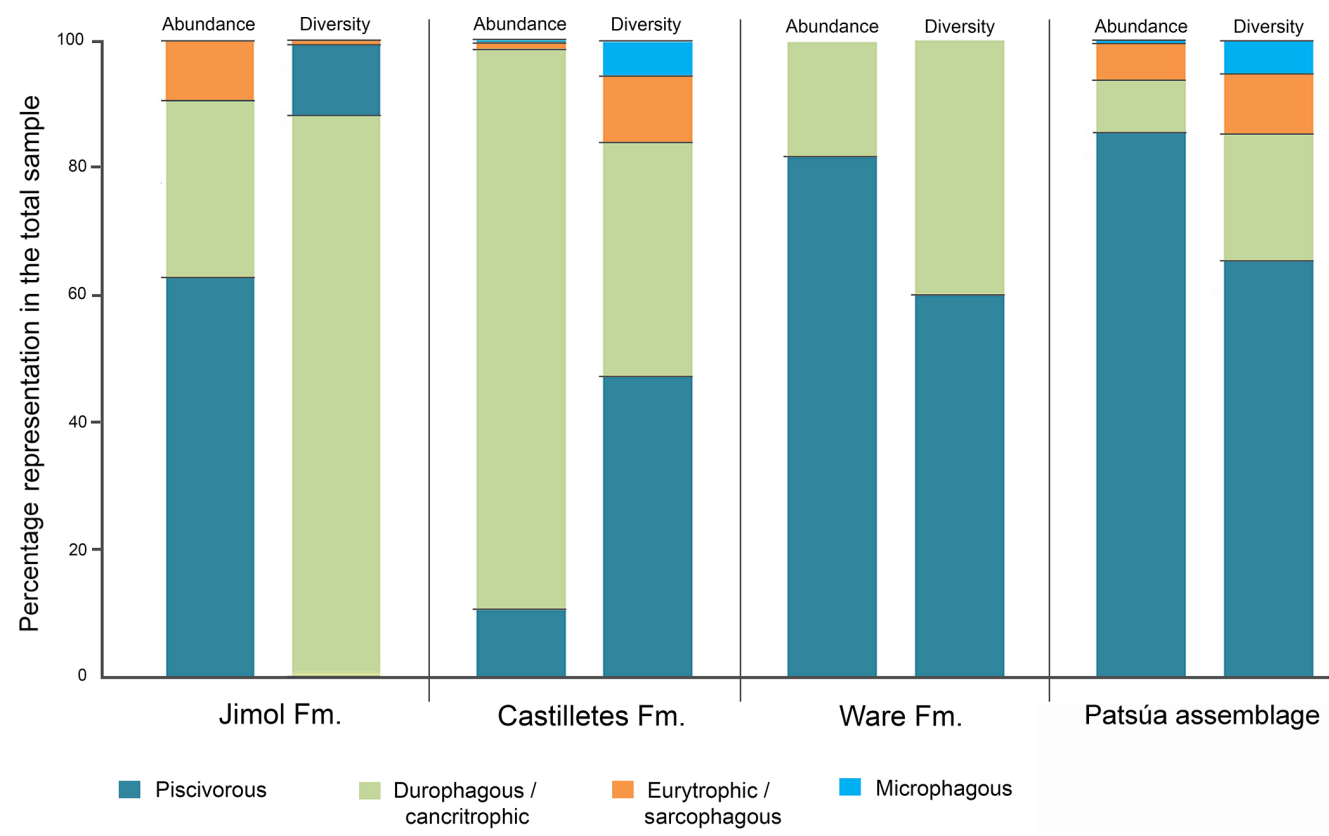

Figure 10. Dietary preferences of the elasmobranch paleofauna from the Cocinetas Basin.

Briceño et al., 2016a; Aguilera et al., 2017a). Due to the scarce fossil record of this extinct species, it is difficult to propose a determined biostratigraphic and geographical range. The absence of this species in other geological units, younger than early Miocene in the Americas or other regions, could suggest that this species is restricted to the early Miocene.

With reference to $\dagger$ Galeocerdo mayumbensis, little is known about its distribution and chronostratigraphy, which has been explained in the scientific literature from a few early Miocene localities of Africa (Dartevelle and Casier, 1943; Andrianavalona et al., 2015; Argyriou et al., 2015) and South America (Carrillo-Briceño et al., 2016a; Aguilera et al., 2017a). According to the morphology of some illustrated teeth (resembling the morphology of those of $\dagger G$. mayumbensis), taxonomical misidentifications could also include specimens from the early Miocene of Africa (Cook et al., 2010, Fig. 3c), Asia (Patnaik et al., 2014, Plate 2.12), Central America (Pimiento et al., 2013, Fig. 4b) and South America (Santos and Travassos, 1960, Fig. 3; Reis, 2005, Fig. 6; Costa et al., 2009, Figs. 1e, 2c), for which a more detailed review of these specimens would be necessary. Abundant unpublished studies on the teeth of $\dagger G$. mayumbensis (labeled in public and private collections) from the east coast of the US questionably have been assigned to a middle to late Miocene and Pliocene age without detailed stratigraphic information. However, many specimens are certainly present at least in the earlier portion of the middle Miocene section of the Bone Valley Formation in Florida (Dana Ehret, personal communication, 2 August 2018). The absence of $\dagger G$. mayumbensis in locations younger than early Miocene (with the exception of the above record Bone Valley Formation) and the tendency of the overall stratigraphical distribution of $\dagger G$. mayumbensis, including the new referenced record of the Castilletes Formation and the Patsúa assemblage (Table S1), could suggest that this extinct tiger shark was probably restricted to the early Miocene and the beginning of middle Miocene, with a widespread distribution.

\subsection{Paleoenvironments of the Cocinetas Basin}

\subsubsection{Faunal assemblage evaluation}

The Neogene sedimentary sequence of the Cocinetas Basin has been characterized by a transition from a shallow marine to a fluvio-deltaic paleoenvironment (e.g., Moreno et al., 2015; Pérez-Consuegra et al., 2018). The geological and paleontological evidence (mainly based on mollusks; see Hendy et al., 2015) of the Jimol Formation indicates depositional conditions characterized by a shallow marine environment (inner shelf depth $<50 \mathrm{~m}$ ). The elasmobranch fauna from the Jimol Formation is characterized by a higher diversity of piscivorous carcharhiniform and lamniform species (Figs. 9-10). However, in this assemblage, durophagous/cancritrophic representatives are the most abundant group (i.e., rays), which are potential prey in marginal marine and brackish environments for piscivorous sharks (see Hendy et al., 2015). This could support habitat and feeding preferences of carcharhiniform and lamniform species in the Jimol Formation. The elasmobranch fauna from the Castilletes Formation is mainly characterized by carcharhiniforms and myliobatiforms, where more than the $80 \%$ of the taxa correspond to durophagous/cancritrophic 
(a)
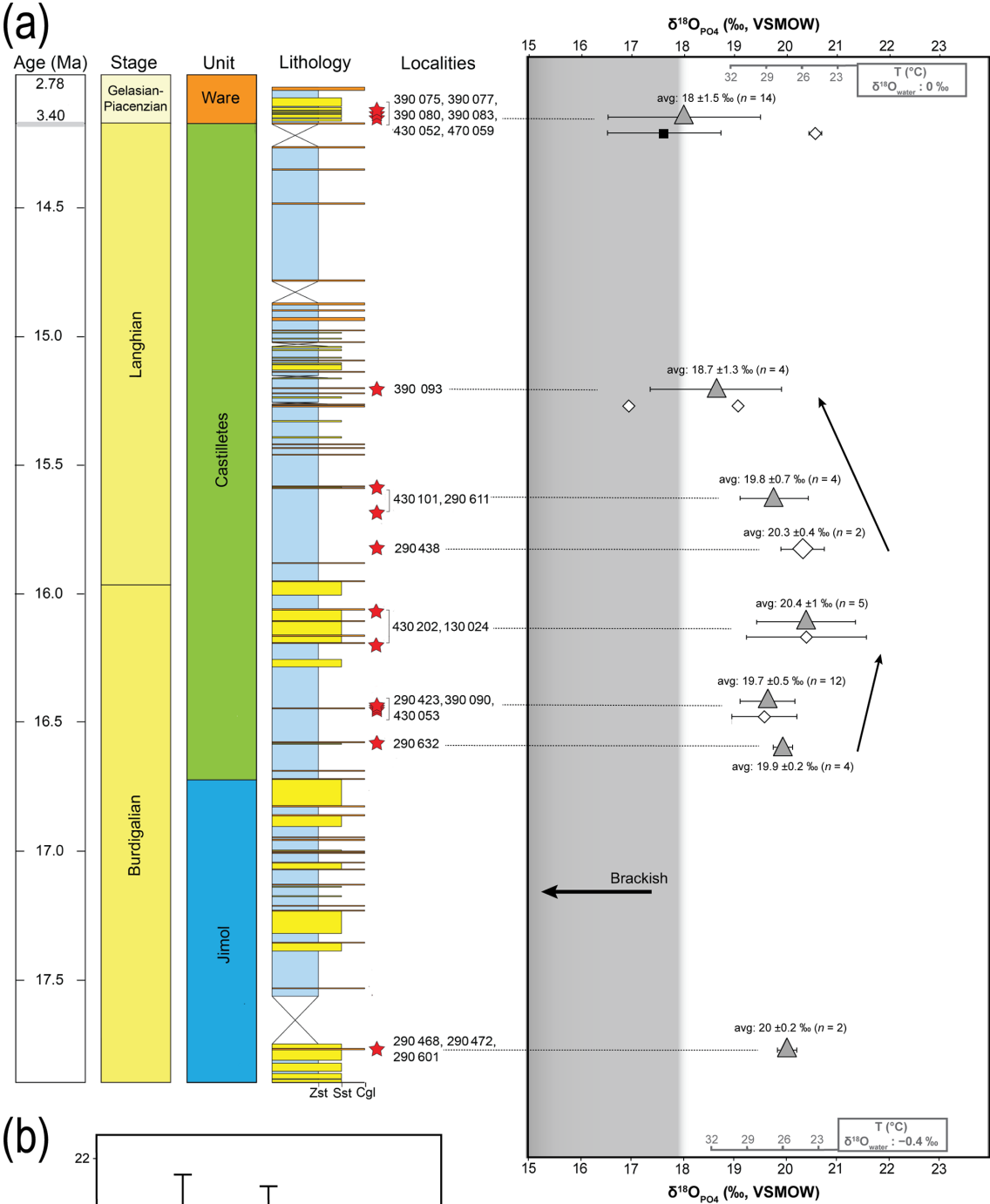

(b)
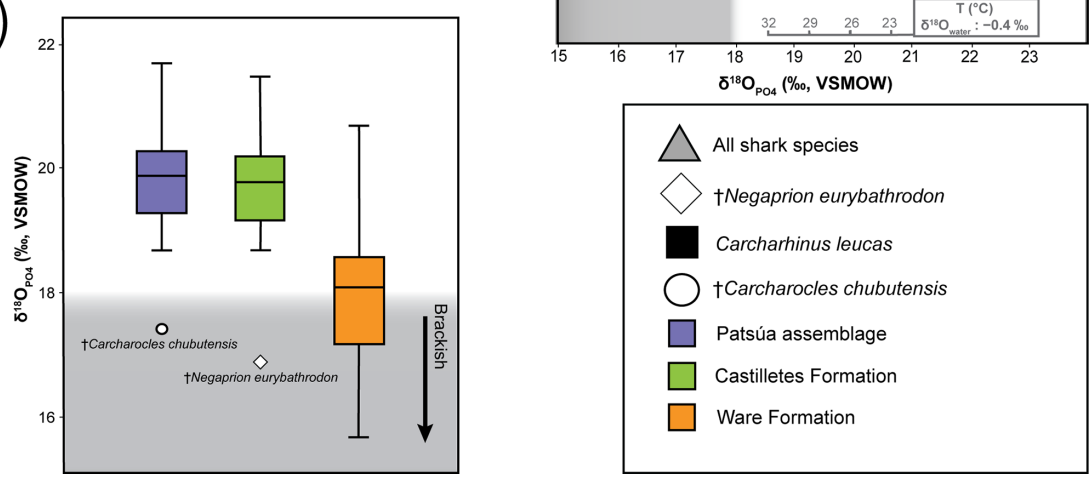

Figure 11. Stratigraphic distribution of the $\delta^{18} \mathrm{O}_{\mathrm{PO}_{4}}$ from sharks of the Cocinetas Basin. The gray-shaded area marks the isotopic range representative of brackish environments. Big symbols give the average of all shark data within the same layer and its standard deviation, while smaller icons are for specific species data. Triangles group all shark species sampled in that layer, while diamonds show the results from $\dagger$ Negaprion eurybathrodon, which is well represented along the sedimentary sequence (the icon is large for locality 290438 because only Negaprion specimens were sampled), and the squares are values from Carcharhinus leucas of the Ware Formation. Temperature bars were estimated from the equation of Lécuyer et al. (2013) and are shown at the top (Ware) and at the bottom (Jimol and Castilletes) at $\delta^{18} \mathrm{O}_{\mathrm{W}}$ of $0 \%$ and $-0.4 \%$, respectively (Lear et al., 2000; Billups and Schrag, 2002). (a) The mean $\delta^{18} \mathrm{O}_{\mathrm{PO}_{4}}$ values show a minor increase along the middle Miocene, with a maximum mean value for localities of the late Burdigalian. In the following intervals, the mean values decrease during the early Langhian. Ware Formation samples have $\delta^{18} \mathrm{OPO}_{4}$ values predominantly characteristic of brackish environments. (b) Box plot of the $\delta^{18} \mathrm{O}_{\mathrm{PO}_{4}}$ values from samples of the Patsúa assemblage and the Castilletes and Ware formations. Each outlier from the Patsúa assemblage and Castilletes show teeth with $\delta^{18} \mathrm{O}_{\mathrm{PO}_{4}}$ values considered to form under brackish conditions. 
feeding preferences (Figs. 9-10) and commonly these fishes are related to marginal marine and brackish environments (see Carrillo-Briceño et al., 2015a, b, and references therein). Abundant marine and terrestrial fossils such as plants, mollusks, crustaceans, fishes, turtles, crocodilians and mammals in the Castilletes Formation suggest a shallow marine to fluvio-deltaic depositional environment, similar to those habitats that characterize the Neogene Urumaco sequence in western Venezuela (Aguilera et al., 2013; CarrilloBriceño et al., 2015b; Cadena and Jaramillo, 2015; Hendy et al., 2015; Moreno et al., 2015; Amson et al., 2016; Moreno-Bernal et al., 2016; Aguirre-Fernández et al., 2017). The elasmobranch fauna of the Castilletes Formation is similar to the Urumaco sequence because it is dominated by durophagous/cancritrophic taxa (such as Aetomylaeus, Rhinoptera and Myliobatoidea indet.) (CarrilloBriceño et al., 2015b). This similarity could be related to the abundance of their potential benthic prey of mollusks and crustaceans. The Patsúa assemblage, especially the locality 290468 , is characterized by a high diversity and abundance of piscivorous carcharhiniform and lamniform species (Figs. 9-10). The presence of the lamniform Isurus cf. I. oxyrinchus, the otodontid $\dagger$ Parotodus benedenii, the alopiids Alopias cf. $\dagger$ A. exigua and $\uparrow$ Anotodus retroflexus, and the pristiophoriform Pristiophorus sp. could suggest a fully marine environment. The associated bony fishes (Acanthuridae, Labridae, Scaridae, Sparidae, Sphyraenidae, Balistidae and Diodontidae, (see Fig. S7), corals, bryozoans, echinoderms and mollusks suggest a subtidal marine environment with limited influence from major freshwater input (see Hendy et al., 2015). The mollusks and echinoderms are distinctive from those of the Jimol and Castilletes formations that have been extensively sampled in central and eastern parts of the Cocinetas Basin. The Patsúa assemblage preserves a diversity of species that covers fully marine sandy bottom and reef habitats (e.g., Spondylus), while freshwater and brackish water species are absent. Other notable fossils include abundant fragments of wood that contain Teredolites (traces of Teredo or shipworm) and Aturia (nautiloid), which presumably were washed up onto a more exposed coastal setting. An isolated and incomplete Odontoceti tooth also was recorded from locality 290472 (specimen MUN-STRI-44517).

In contrast with the diverse early-middle-Miocene elasmobranch assemblages of the Jimol and Castilletes formations and the Patsúa assemblage, the fauna of the late Pliocene Ware Formation is low in diversity and abundance (Figs. 9, S5, Tables S1-S3). In the same conglomeraticfossiliferous layer where the elasmobranchs come from, abundant fishes, turtles, crocodilians and mammals have also been found (Moreno et al., 2015; Amson et al., 2016; Moreno-Bernal et al., 2016; Pérez et al., 2016). A fluviodeltaic depositional environment has been described for the basal portion of the Ware Formation (Moreno et al., 2015; Pérez-Consuegra et al., 2018). Carcharhinus leucas, $\dagger$ Negaprion eurybathrodon, Pristis sp. and Rhinoptera sp. are the only representative chondrichthyan species for this unit (Table S1). These species are able to inhabit both marine and brackish environments (Feldheim et al., 2002; Matich and Heithaus, 2013; Ebert and Stehmann, 2013; Ebert et al., 2013; Carlson et al., 2013; Carrillo-Briceño et al., 2015b). Carcharhinus leucas and Pristis also have the capacity to enter into rivers and live permanently in freshwater lakes (Voigt and Weber, 2011; Faria et al., 2013).

\subsection{Paleoenvironmental reconstruction based on the $\delta^{18} \mathrm{O}_{\mathrm{PO}_{4}}$ data}

The $\delta^{18} \mathrm{O}$ values of biogenic phosphate are related to the $\mathrm{O}$ isotope composition of the water and their temperature of formation (e.g., Longinelli and Nuti, 1973a; Kolodny et al., 1983). While open-ocean waters are generally quite homogeneous in isotopic composition (close to $0 \%$ ), all meteoric waters are ultimately derived from marine waters by evaporation, which fractionates the isotopic composition of the $\mathrm{H}_{2} \mathrm{O}$ molecules such that freshwater will generally have lower $\delta^{18} \mathrm{O}$ values compared to seawater (Hoefs, 2015). As such, $\delta^{18} \mathrm{OPO}_{4}$ values less than $18.4 \%$ o likely formed in waters that are not exclusively marine $\left(\delta^{18} \mathrm{O}_{\mathrm{w}}=0 \%\right.$ ). Fishes which form their bioapatite in freshwater-influenced settings with less than $0 \%$ o $\delta^{18} \mathrm{O}_{\mathrm{w}}$ values (e.g., rivers, lakes) also have lower $\delta^{18} \mathrm{O}_{\mathrm{PO}_{4}}$ values at the same ambient temperature (Longinelli and Nuti, 1973a; Kolodny et al., 1983; Kocsis et al., 2007; Fischer et al., 2013a; Leuzinger et al., 2015). Samples with low $\delta^{18} \mathrm{O}_{\mathrm{PO}_{4}}$ values may thus indicate the presence of brackish-like environments. Because the oceans are generally well mixed and freshwater influence in terms of absolute volume in many cases is minor compared to seawater, the temperatures calculated are estimates only and their accuracy is related to the amount of freshwater influence. For simplicity, we therefore take values of $\delta^{18} \mathrm{O}$ below about $18.4 \%$ o as a clear indication of a significant freshwater influence as the temperatures calculated based on an estimate of $0 \%$ o seawater are too high for any typical shark habitat. Clearly, the exact temperature of formation cannot be estimated as this would require the precise knowledge of the $\delta^{18} \mathrm{O}$ value for these brackish waters.

Nonetheless, shark tooth $\delta^{18} \mathrm{O}_{\mathrm{PO}_{4}}$ values can be used to qualitatively estimate paleoenvironmental conditions for the Patsúa assemblage and the Castilletes and Ware formations (Fig. 11).

- Patsúa assemblage. The age of this fauna is not as well established as it is for the other sites; therefore the obtained isotopic values represent paleoenvironmental conditions somewhere within the Burdigalian and Langhian periods. These shark teeth had predominantly marine isotopic compositions with one low $\delta^{18} \mathrm{O}_{\mathrm{PO}_{4}}$ value measured from a $\dagger$ Carcharocles chubutensis specimen (CC.4: 17.4 $\pm 0.3 \%$ o, Table 2, Fig. 11b). This isotopic composition is typical for brackish waters although $\dagger$ Carcharocles chubutensis utilized a habitat 
similar to the recent great white shark (Carcharodon carcharias). Most of the isotopic data for the extant and fossil species of lamniform sharks are characteristic of cold waters, because of its long oceanic migrations and formation of bioapatite in such cold settings (Barrick et al., 1993; Vennemann et al., 2001; Amiot et al., 2008; Ebert et al., 2013; Aguilera et al., 2017a). Therefore, the low $\delta^{18} \mathrm{O}_{\mathrm{PO}_{4}}$ value from this species is quite surprising and may indicate some hidden habitat trait for this ancient shark. Statistical comparisons using available data sets demonstrate this assemblage is indistinguishable from the Castilletes Formation (Fig. 11b). Possibly these paleoenvironments were similar and based on the $\delta^{18} \mathrm{OPO}_{4}$ values; the Patsúa assemblage was deposited mainly under marine conditions. Nevertheless, additional sampling and a precise chronological dating of this assemblage are necessary to improve the interpretation of its isotopic data.

- Castilletes Formation. The sedimentary sequence of the Cocinetas Basin is described as a transition from a shallow marine to a fluvio-deltaic paleoenvironment (i.e., a regression). Similar to the results from the Patsúa assemblage, the $\delta^{18} \mathrm{O}_{\mathrm{PO}_{4}}$ values are predominantly marine, except for a single tooth of $\dagger$ Negaprion eurybathrodon (NG.14: $16.7 \pm 0.2 \%$, Fig. 11a, b). Extant individuals of this genus inhabit marine inshore areas and commonly migrate through enclosed bays or river mouths, supporting an isotopic freshwater-influenced habitat (Castro, 1993; Feldheim et al., 2002). In fact, more samples covering the brackish range were expected, since the fossil assemblage of the Castilletes Formation suggests a deltaic influence at this interval (Moreno et al., 2015). Paleobathymetric estimates using mollusks have shown that the paleoenvironments were alternating quickly along the stratigraphic succession, like a transgressive-regressive cycle (Hendy et al., 2015). The $\delta^{18} \mathrm{O}_{\mathrm{PO}_{4}}$ mean values show a minor increase from the base towards the middle section of Castilletes $(20.4 \pm 1.0 \%, n=5$, Fig. 11a), decreasing thereafter to the lowest mean value in this formation $(18.7 \pm 1.3 \%$, $n=4)$. This possibly indicates regional changes in the paleoenvironment of shark habitats (e.g., marine to estuarine). However, because the overall deviation is overlapping between the localities, more samples would be required to refine this interpretation. While the overall shark isotope data do not require brackish conditions during the deposition of the Castilletes Formation, the occasional outliers (Fig. 11a, b), notably for specimens known to migrate into freshwater, support either a seasonal influence of freshwater and/or the presence of brackish waters into which some species may have migrated temporarily. This interpretation is in agreement with the higher-resolution mollusk data from the region (Hendy et al., 2015).
- Ware Formation. The isotope data are significantly different for the Ware Formation from the Patsúa assemblage and the Castilletes Formation (except for locality 390093, Fig. 11a, b). The $\delta^{18} \mathrm{O}_{\mathrm{PO}_{4}}$ values are generally lower in this formation, especially for $\mathrm{Car}$ charhinus leucas (CL.1-CL.12: $17.6 \pm 1.1 \%, n=12$ ). This euryhaline species, like Negaprion brevirostris, also inhabits marine inshore zones and occasionally migrates into brackish environments. However, modern Carcharhinus leucas is well known for its ability to persist in coastal environments with brackish conditions, as individuals can also swim hundreds of meters upstream into freshwater (Matich and Heithaus, 2013; Ebert et al., 2013). The isotopic range for the Ware Formation sharks is in agreement with the fluviodeltaic paleoenvironment of deposition described for this formation (Moreno et al., 2015; Pérez-Consuegra et al., 2018) and also with the euryhaline predominant fauna presented here (Pristis sp., C. leucas, Rhinoptera sp., †Negaprion eurybathrodon). The two samples of $\dagger$ Negaprion eurybathrodon have $\delta^{18} \mathrm{O}_{\mathrm{PO}_{4}}$ values which probably formed under distinct marine conditions rather than under fluvial influence (NG.15: $20.7 \pm 0.1 \%$; NG.16: $20.5 \pm 0 \%$ ). The worn appearances of the teeth from the conglomerate beds of the Ware Formation indicate longer transport and hence also probably a mixed, time-averaged fauna originating from different layers within a wider fluvio-deltaic system. Therefore, while the Carcharhinus leucas specimens reflect clear fluvial conditions, the $\dagger$ Negaprion eurybathrodon teeth may have been derived from layers originally deposited in a prodelta or nearby shallow coastal marine beds. Eventually, these Negaprion teeth grown under marine conditions could have been lost in the fluvio-deltaic paleoenvironment exploited by the sharks.

Carcharhinus leucas teeth are also smaller compared to other specimens (and species) utilized in this study. Modern representatives of adult Carcharhinus leucas normally have anterior teeth around $2 \mathrm{~cm}$ in height (Ebert et al., 2013, personal observation), a size considerably larger than our sampled teeth $(<1 \mathrm{~cm}$, Fig. S8). In previous stable isotope investigations, only samples from juvenile specimens from Lake Nicaragua provided $\delta^{18} \mathrm{OPO}_{4}$ values characteristic of a brackish condition (Kocsis et al., 2015; Aguilera et al., 2017a). Today, young specimens of this group are known for using brackish lagoons from areas adjacent to the Cocinetas Basin as a nursery ground (e.g., Lake Maracaibo, Rodríguez, 2001, Tavares and Sánchez, 2012). Moreover, the predominant brackish-like $\delta^{18} \mathrm{O}_{\mathrm{PO}_{4}}$ values in this species may imply that at least since the late Pliocene they were already adapted to live in waters with reduced salinity and face the constant environmental changes (global and regional) of their paleohabitats. 


\section{Conclusions}

- A diverse elasmobranch fauna containing 30 taxa of sharks and rays was identified, with the most diverse groups being Carcharhiniformes and Lamniformes, respectively. The fossil assemblage seems to agree with paleoenvironmental descriptions from previous studies for the fossiliferous formations of the Cocinetas Basin (Jimol, Castilletes and Ware).

- An elasmobranch assemblage (Patsúa fauna) is reported from undifferentiated facies of the Jimol and Castilletes formations and represents a subtidal marine environment with limited freshwater influence.

- The biogenic phosphate $\delta^{18} \mathrm{O}_{\mathrm{PO}_{4}}$ values of 73 shark teeth are evaluated within the sedimentary sequence of the Cocinetas Basin. The isotopic data are used to estimate paleoenvironmental settings (e.g., marine vs. brackish vs. freshwater), corroborating descriptions for Castilletes and Ware formations.

- A predominant brackish-like $\delta^{18} \mathrm{O}_{\mathrm{PO}_{4}}$ value was measured for Carcharhinus leucas, suggesting that at least since the late Pliocene this species was already well adapted to migrate into habitats with reduced salinity.

- More samples and additional proxies are recommended to refine our interpretations. Nevertheless, this multidisciplinary study certainly complements the knowledge about the paleoenvironmental context and evolution of tropical America.

Data availability. The raw isotopic data and corrections can be found in https://doi.org/10.5281/zenodo.2390875 (Carrillo-Briceño et al., 2018).

Supplement. The supplement related to this article is available online at: https://doi.org/10.5194/bg-16-33-2019-supplement.

Author contributions. The conceptualization was carried out by JDCB and AH. Data curation, formal analysis and investigation were performed by JCDB and ZL. Funding acquisition was supported by JDCB, AH and TV. Methodology was set by JCDB and ZL with contributions from all co-authors. Resources were provided by JCDB, AH and TV. Supervision was provided by AH, TV and OA. Validation was discussed with LK, TV and OA. Visualization was done by JDCB, ZL and LK. The writing of the original draft was performed by JDCB and ZL with contributions from all coauthors, and the review and editing was done by $\mathrm{ZL}$ with substantial contributions from all co-authors.

Competing interests. The authors declare that they have no conflict of interest.
Acknowledgements. This work was supported by the Swiss National Science Foundation (SNF 31003A-149605 to MRSV, SNF 200020-160055/1 to Zoneibe Luz and Torsten Vennemann) and by the Smithsonian Tropical Research Institute (National Geographic Society, Anders Foundation, Gregory D. and Jennifer Walston Johnson, 1923 Fund, Universidad del Norte and National Science Foundation EAR 0957679 to Carlos Jaramillo). The authors wish to especially thank to Henri Cappetta, Sylvain Adnet, Loic Costeur, Rene Kindlimann, Gustavo Ballen and the Wayuu communities of the Alta Guajira for their generous and important counseling, permission for collection revision and collaboration. Participants of fieldwork in Alta Guajira (2009-2014) are thanked for their assistance in collection of samples. Special thanks to the Center for Microscopy and Image Analysis of the University of Zurich for their assistance and support performing the scanning electron microscopy analysis. Zoneibe Luz would like to thank Thiago Nascimento for all technical assistance to build the manuscript file. We are thankful to the Alcaldía Bolivariana de Urumaco; the Universidad Experimental Francisco de Miranda; the Mapuka Museum of the Universidad del Norte (Barranquilla, Colombia); the Natural History Museum of Basel (Switzerland); the paleontological collection of the Institut des Sciences de l'Evolution, University of Montpellier (France); and the Palaeontological Institute and Museum at the University of Zurich for their valuable assistance and for access to comparative material. Authors are thankful to Dana Ehret and the anonymous reviewer for the contributions to improve the manuscript and to Alberto Collareta for his support of our research. Last but not least, thanks to the Editor David Gillikin for the manuscript handling.

Edited by: David Gillikin

Reviewed by: Dana Ehret and one anonymous referee

\section{References}

Agassiz, L.: Recherches sur les poissons fossiles, Neuchâtel, Petitpierre, 188 pp., 1835-1845.

Agassiz, L.: Remarks on a new species of skate from the Sandwich islands, Proceedings of the Boston Society of Natural History, 6, p. $385,1958$.

Aguilera, O.: Peces fósiles del Caribe de Venezuela, Gorham Printing, Washington, 2010.

Aguilera, O. and Lundberg, J. G.: Venezuelan Caribbean and Orinocoan Neogene fish, in: Urumaco and Venezuelan Paleontology, edited by: Sánchez-Villagra, M. R., Aguilera, O., and Carlini, F., Indiana Press University, Bloomington, 129-152, 2010.

Aguilera, O., Moraes-Santos, H., Costa, S., Ohe, F., Jaramillo, C., and Nogueira, A.: Ariid sea catfishes from the coeval Pirabas (Northeastern Brazil), Cantaure, Castillo (Northwestern Venezuela), and Castilletes (North Colombia) formations (Early Miocene), with description of three new species, Swiss Journal of Palaeontology, 132, 45-68, 2013.

Aguilera, O., Luz, Z., Carrillo-Briceño, J. D., Kocsis, L., Vennemann, T., de Toledo, P. M., Nogueira, A., Amorim, K. B., Moraes-Santos, H., Polck, M. R., Ruivo, M. L., Linhares, A. P., and Monteiro-Neto, C.: Neogene sharks and rays from the Brazilian "Blue Amazon", PLoS One, 12, e0182740, https://doi.org/10.1371/journal.pone.0182740, $2017 \mathrm{a}$. 
Aguilera, O., Silva, G. O. A., Lopes, R. T., Machado, A. S., and dos Santos, T. M.: Neogene Proto-Caribbean porcupinefishes (Diodontidae), PLoS One, 12, e0181670, https://doi.org/10.1371/journal.pone.0181670, 2017 b.

Aguirre-Fernández, G., Carrillo-Briceño, J. D., Sánchez, R., Amson, E., and Sánchez-Villagra, M. R.: Fossil Cetaceans (Mammalia, Cetacea) from the Neogene of Colombia and Venezuela, J. Mamm. Evol., 24, 71-90, 2017.

Ameghino, F.: L'âge des formations sédimentaires de Patagonie, Anales de la Sociedad Científica Argentina, 51, 65-91, 1901.

Amiot, R., Göhlich, U. B., Lécuyer, C., de Muizon, C., Cappetta, H., Héran, M.-A., and Martineau, F.: Oxygen isotope compositions of phosphate from middle Miocene-early Pliocene marine vertebrates of Peru, Palaeogeogr. Palaeocl., 264, 85-92, https://doi.org/10.1016/j.palaeo.2008.04.001, 2008.

Amson, E., Carrillo, J. D., and Jaramillo, C.: Neogene sloth assemblages (Mammalia, Pilosa) of the Cocinetas basin (la Guajira, Colombia): implications for the Great American Biotic Interchange, Palaeontology, 59, 563-582, 2016.

Andrianavalona, T. H., Ramihangihajason, T. N., Rasoamiaramanana, A., Ward, D. J., Ali, J. R., and Samonds, K. E.: Miocene shark and batoid fauna from Nosy Makamby (Mahajanga Basin, Northwestern Madagascar), PLoS One, 10, e0129444, https://doi.org/10.1371/journal.pone.0129444, 2015.

Applegate, S. P.: A revision of the higher taxa of Orectoloboids, Journal of the Marine Biological Association of India, 14, 743751,1972

Argyriou, T., Cook, T. D., Muftah, A. M., Pavlakis, P., Boaz, N. T., and Murray, A. M.: A fish assemblage from an early Miocene horizon from Jabal Zaltan, Libya, J. Afr. Earth Sci., 102, 86-101, 2015.

Bacon, C. D., Silvestro, D., Jaramillo, C., Smith, B. T., Chakrabarty, P., and Antonelli, A.: Biological evidence supports an early and complex emergence of the Isthmus of Panama, P. Natl. Acad. Sci. USA, 112, 6110-6115, 2015.

Barrick, R. E., Fischer, A. G., and Bohaska, D. J.: Paleotemperatures versus sea level: oxygen isotope signal from fish bone phosphate of the Miocene Calvert Cliffs, Maryland, Paleoceanography, 8, 845-858, https://doi.org/10.1029/93PA01412, 1993.

Berg, L. S.: A classification of fish-like vertebrates, Bulletin of the Academy of Sciences of the USSR, Division of Chemical Science, 4, 1277-1280, 1937.

Berg, L. S.: System der Rezenten und Fossilen Fischartigen und Fische, Deutscher Verlag Wissensch, Berlin, 1958.

Billups, K. and Schrag, D. P.: Paleotemperatures and ice volume of the past 27 myr revisited with paired $\mathrm{Mg} / \mathrm{Ca}$ and ${ }^{18} \mathrm{O} /{ }^{16} \mathrm{O}$ measurements on benthic foraminifera, Paleoceanography, 17, 3-11, https://doi.org/10.1029/2000PA000567, 2002.

Blainville, H. M. D.: Prodrome d'une nouvelle distribution systematique du regne animal, Bulletin de la Société Philomathique de Paris, 8, 113-124, 1816.

Blake, C. C.: Shark's teeth at Panama, Geologist, 5, p. 316, 1862.

Bonnaterre, J. P.: Tableau encyclopédique et méthodique des trois règnes de la nature, Ichthyologie, Panckoucke, Paris, 1788.

Bor, T. J., Reinecke, T., and Verschueren, S.: Miocene Chondrichthyes from Winterswijk - Miste, the Netherlands, Palaeontos, 21, 1-136, 2012.

Cadena, E. and Jaramillo, C.: Early to middle Miocene turtles from the northernmost tip of South America: Giant Testudinids, Che- lids, and Podocnemidids from the Castilletes Formation, Colombia, Ameghiniana, 52, 188-203, 2015.

Cappetta, H.: Les Sélaciens du Miocène de la région de Montpellier, Palaeovertebrata, Mémoire Extraordinaire, 1-139, 1970.

Cappetta, H.: Chondrichthyes. Mesozoic and Cenozoic Elasmobranchii: Teeth, vol. 3E, Verlag Dr. Friedrich Pfeil, Munich, 2012.

Carlson, J. K., Gulak, S. J. B., Simpfendorfer, C. A., Grubbs, R. D., Romine, J. G., and Burgess, G. H.: Movement patterns and habitat use of smalltooth sawfish, Pristis pectinata, determined using pop-up satellite archival tags, Aqua. Conserv., 24, 104-117, https://doi.org/10.1002/aqc.2382, 2013.

Carrillo-Briceño, J. D., Aguilera, O., and Rodríguez, F.: Fossil Chondrichthyes from the central eastern Pacific Ocean and their paleoceanographic significance, J. S. Am. Earth Sci., 51, 76-90, 2014.

Carrillo-Briceño, J. D., de Gracia, C., Pimiento, C., Aguilera, O., Kindlimann, R., Santamarina, P., and Jaramillo, C.: A new late Miocene chondrichthyan assemblage from the Chagres Formation, Panama, J. S. Am. Earth Sci., 60, 56-70, 2015 a.

Carrillo-Briceño, J. D., Maxwell, E., Aguilera, O., Sánchez, R., and Sánchez-Villagra, M. R.: Sawfishes and other elasmobranch assemblages from the Mio-Pliocene of the South Caribbean (Urumaco Sequence, Northwestern Venezuela), PLoS One, 10, e0139230, https://doi.org/10.1371/journal.pone.0139230, 2015b.

Carrillo-Briceño, J. D., Aguilera, O., de Gracia, C., AguirreFernández, G., Kindlimann, R., and Sánchez-Villagra, M. R.: An early Neogene elasmobranch fauna from the southern Caribbean (Western Venezuela), Palaeontol. Electron., 19.2.27A, 1-32, 2016a.

Carrillo-Briceño, J. D., Argyriou, T., Zapata, V., Kindlimann, R., and Jaramillo, C.: A new early Miocene (Aquitanian) Elasmobranchii assemblage from the Guajira Peninsula, Colombia, Ameghiniana, 53, 77-99, 2016b.

Carrillo-Briceño, J. D., Luz, Z., Hendy, A., Kocsis, L., Aguilera, O., and Vennemann, T.: Carrillo-Briceño et al. 2018 raw isotopic data, https://doi.org/10.5281/zenodo.2390875, 2018.

Casier, E.: Contribution à l'étude des poissons fossiles des Antilles, Mémoire Suisse de Paléontologie, 74, 1-95, 1958.

Casier, E.: Sur la faune ichthyologique de la Formation de Bissex Hill et de la Série océanique, de l'Ile de la Barbade, et sur l'âge de ces formations, Eclogae Geol. Helv., 59, 493-516, 1966.

Castro, J. I.: The shark nursery of Bulls Bay, South Carolina, with a review of the shark nurseries of the southeastern coast of the United States, Environ. Biol. Fish., 38, 37-48, 1993.

Coates, A. G. and Stallard, R. F.: How old is the Isthmus of Panama?, B. Mar. Sci., 89, 801-813, 2013.

Compagno, L. J. V.: Interrelationships of living elasmobranchs, in: Interrelationships of fishes, edited by: Greenwood, P. H., Miles, R. S., and Patterson, C., Academic Press, London, 15-61, 1973.

Compagno, L. J. V.: Appendix 1: Global Checklist of living Chondrichthyan Fishes, in: Sharks, rays and chimaeras: The status of the chondrichthyan fishes, edited by: Fowler, S. L., Cavanagh, R. D., Camhi, M., Burgess, G. H., Cailliet, G. M., Fordham, S. V., Simpfendorfer, C. A., and Musick, J. A., p. 401-423, IUCN The World Conservation Union, Oxford, UK, 2005.

Compagno, L. J. V., Dando, M., and Fowler, S. L.: Sharks of the World, Princeton University Press, Princeton, 2005. 
Cook, T. D., Murray, A. M., Simons, E. L., Attia, Y. S., and Chatrath, P.: A Miocene selachian fauna from Moghra, Egypt, Hist. Biol., 22, 78-87, 2010.

Cope, E. D.: An addition to the vertebrate fauna of the Miocene period, with a synopsis of the extinct Cetacea of the United States, P. Acad. Nat. Sci. Phila., 19, 138-156, 1867.

Cope, E. D.: Descriptions of some extinct fishes previously unknown, Proceedings of the Boston Society of Natural History, 12, 310-319, 1869.

Cortés, E., Papastamatiou, Y. P., Carlson, J. K., Ferry-Graham, L., and Wetherbee, B. M.: An overview of the feeding ecology and physiology of elasmobranch fishes, in: Feeding and digestive functions in fishes, edited by: Cyrino, J. E. P., Bureau, D. P., and Kapoor, B. G., Science Publishers, Florida, 393-443, 2008.

Costa, S. A. F., Richter, M., de Toledo, P. M., and Moraes-Santos, H.: Shark teeth from Pirabas Formation (lower Miocene), northeastern Amazonia, Brazil, Boletim do Museu Paraense Emílio Goeldi, 4, 221-230, 2009.

Cuvier, G. L. C. F. D.: Le règne animal, distribué d'après son organisation, pour servir de base à l'histoire naturelle des animaux et d'introduction à l'anatomie comparée, l'Imprimerie de A. Belin, Paris, Déterville, 2nd Edn., 1829.

Dartevelle, E. and Casier, E.: Les poissons fossiles du Bas-Congo et des régions voisines, Annales du Musée du Congo Belge, Série A (Minéralogie Géologie, Paléontologie), 2, 1-200, 1943.

Dettman, D. L., Kohn, M. J., Quade, J., Ryerson, F. J., Ojha, T. P., and Hamidullah, S.: Seasonal stable isotope evidence for a strong Asian monsoon throughout the past 10.7 m.y, Geology, 29, 3134, 2001.

Ebert, D. A. and Stehmann, M. F. W.: Sharks, batoids, and chimaeras of the North Atlantic, Food and Agriculture Organization of the United Nations, Roma, 2013.

Ebert, D. A., Fowler, S. L., Compagno, L. J. V., and Dando, M.: Sharks of the world, Wild Nature Press, Plymouth, 2013.

Faria, V. V., Mcdavitt, M. T., Charvet, P., Wiley, T. R., Simpfendorfer, C. A., and Naylor, G. J. P.: Species delineation and global population structure of Critically Endangered sawfishes (Pristidae), Zool. J. Lin. Soc.-London, 167, 136-164, 2013.

Farris, D. W., Jaramillo, C., Bayona, G., Restrepo-Moreno, S. A., Montes, C., Cardona, A., Mora, A., Speakman, R. J., Glascock, M. D., and Valencia, V.: Fracturing of the Panamanian Isthmus during initial collision with South America, Geology, 39, 1007 1010, 2011.

Feldheim, K. A., Gruber, S. H., and Ashley, M. V.: The breeding biology of lemon sharks at a tropical nursery lagoon, P. Roy. Soc. London B, 269, 1655-1661, https://doi.org/10.1098/rspb.2002.2051, 2002.

Fischer, J., Voigt, S., Franz, M., Schneider, J. W., Joachimski, M., Tichomirowa, M., Götze, J., and Furrer, H.: Palaeoenvironments of the late Triassic Rhaetian Sea: implications from oxygen and strontium isotopes of hybodont shark teeth, Palaeogeogr. Palaeocl., 353-355, 60-72, 2012.

Fischer, J., Schneider, J. W., Hodnett, J.-P. M., Elliott, D. K., Johnson, G. D., Voigt, S., Joachimski, M., Tichomirowa, M., and Götze, J.: Stable and radiogenic isotope analysis on shark teeth from the early to the middle Permian (Sakmarian - Roadian) of the southwestern USA, Hist. Biol., 26, 710-727, $2013 \mathrm{a}$.

Fischer, J., Schneider, J. W., Voigt, S., Joachimski, M., Tichomirowa, M., Tütken, T., Götze, J., and Berner, U.: Oxygen and strontium isotopes from fossil shark teeth: environmental and ecological implications for late Palaeozoic European basins, Chem. Geol., 342, 44-62, 2013 b.

Froese, R. and Pauly, D.: FishBase, available at: http://www. fishbase.org/ (last access: 17 December 2018), 2017.

Garman, S.: The Plagiostomia (Sharks, Skates and Rays), Memoirs of the Museum of Comparative Zoology at Harvard College, 36, $1-528,1913$.

Gibbes, R. W.: Monograph of the fossil Squalidae of the United States, Journal of the Academy of Natural Sciences of Philadelphia, 1, 191-206, 1849.

Gill, T.: Arrangement of the families of fishes or Classes Pisces, Marsipobranchii, and Leptocardii prepared for the Smithsonian Institution by Theodore Gill, Smithsonian Institution Miscellaneous Collection, 1872.

Goodrich, E. S.: Vertebrata Craniata (First fascicle: Cyclostomes and Fishes), in: A treatise on Zoology, edited by: Lankester, R., Adam and Charles Black, London, 1-518, 1909.

Günther, A.: Catalogue of the fishes in the British Museum, British Museum (Natural History), London, 1870.

Hasse, K. E.: Das natürliche System der Elasmobranchier auf Grundlage des Baues und der Entwicklung ihrer Wirbelsäule: eine morphologische und paläontologische Studie, Gustav Fischer Verlag, Jena, 1879.

Hendy, A. J. W., Jones, D. S., Moreno, F., Zapata, V., and Jaramillo, C.: Neogene molluscs, shallow marine paleoenvironments, and chronostratigraphy of the Guajira Peninsula, Colombia, Swiss Journal of Palaeontology, 134, 45-75, 2015.

Hoefs, J.: Hydrosphere, in: Stable isotope geochemistry, edited by: Hoefs, J., Springer, Göttingen, Germany,239-253, 2015.

Iturralde-Vinent, M. A. and MacPhee, R. D. E.: Paleogeography of the Caribbean region: implications for Cenozoic biogeography, B. Am. Mus. Nat. Hist., 238, 1-95, 1999.

Jaramillo, C., Montes, C., Cardona, A., Silvestro, D., Antonelli, A., and Bacon, C. D.: Comment (1) on Formation of the "Isthmus of Panama” by O'Dea et al., Science Advances, 3, e1602321, https://doi.org/10.1126/sciadv.1602321, 2017.

Jordan, D. S. and Evermann, B. W.: The fishes of North and Middle America: a descriptive catalogue of the species of fish-like vertebrates found in the waters of North America, north of the Isthmus of Panama. Part I, Bulletin of the United States National Museum, 47, 1-1240, 1896.

Klimley, P. A.: The biology of sharks and rays, The University of Chicago Press, Chicago, 2013.

Klug, S., Tütken, T., Wings, O., Pfretzschner, H.-U., and Martin, T.: A late Jurassic freshwater shark assemblage (Chondrichthyes, Hybodontiformes) from the southern Junggar Basin, Xinjiang, Northwest China, Palaeobio. Palaeoenv., 90, 241-257, https://doi.org/10.1007/s12549-010-0032-2, 2010.

Koch, P. L., Tuross, N., and Fogel, M. L.: The effects of sample treatment and diagenesis on the isotopic integrity of carbonate in biogenic hydroxylapatite, J. Archaeol. Sci., 24, 417-429, 1997.

Kocsis, L.: Geochemical compositions of marine fossils as proxies for reconstructing ancient environmental conditions, Chimia, 65, 787-791, 2011.

Kocsis, L., Vennemann, T., and Fontignie, D.: Migration of sharks into freshwater systems during the Miocene and implications for Alpine paleoelevation, Geology, 35, 451-454, 2007. 
Kocsis, L., Gheerbrant, E., Mouflih, M., Cappetta, H., Yans, J., and Amaghzaz, M.: Comprehensive stable isotope investigation of marine biogenic apatite from the late Cretaceous-early Eocene phosphate series of Morocco, Palaeogeogr. Palaeocl., 394, 7488, 2014.

Kocsis, L., Vennemann, T., Ulianov, A., and Brunnschweiler, J. M.: Characterizing the bull shark Carcharhinus leucas habitat in Fiji by the chemical and isotopic compositions of their teeth, Environ. Biol. Fish., 98, 1609-1622, https://doi.org/10.1007/s10641015-0386-4, 2015.

Kolodny, Y., Luz, B., and Navon, O.: Oxygen isotope variations in phosphate of biogenic apatites, I. Fish bone apatite-rechecking the rules of the game, Earth Planet. Sc. Lett., 64, 398-404, https://doi.org/10.1016/0012-821X(83)90100-0, 1983.

Kruckow, T. and Thies, D.: Die Neoselachier der Paleokaribik (Pisces: Elasmobranchii), Courier Forschungsinstitut Sencken, 119, 1-102, 1990.

Landini, W., Altamirano-Sierra, A., Collareta, A., di Celma, C., Urbina, M., and Bianucci, G.: The late Miocene elasmobranch assemblage from Cerro Colorado (Pisco Formation, Peru), J. S. Am. Earth Sci., 73, 168-190, 2017.

Last, P. R., Séret, B., and Naylor, G. J.: A new species of guitarfish, Rhinobatos borneensis sp. nov. with a redefinition of the family-level classification in the order Rhinopristiformes (Chondrichthyes: Batoidea), Zootaxa, 4117, 451-475, 2016.

Lear, C. H., Elderfield, H., and Wilson, P. A.: Cenozoic deep-sea temperatures and global ice volumes from $\mathrm{Mg} / \mathrm{Ca}$ in benthic foraminiferal calcite, Science, 287, 269-272, https://doi.org/10.1126/science.287.5451.269, 2000.

Lécuyer, C.: Oxygen isotope analysis of phosphate, in: Handbook of Stable Isotope Analytical Techniques, edited by: de Groot, P. A., Elsevier, vol. 1, 482-499, 2004.

Lécuyer, C., Grandjean, P., O’Neil, J. R., Cappetta, H., and Martineau, F.: Thermal excursions in the ocean at the CretaceousTertiary boundary (northern Morocco): $\delta^{18} \mathrm{O}$ record of phosphatic fish debris, Palaeogeogr. Palaeocl., 105, 235-243, https://doi.org/10.1016/0031-0182(93)90085-W, 1993.

Lécuyer, C., Grandjean, P., Paris, F., Robardet, M., and Robineau, D.: Deciphering "temperature" and "salinity" from biogenic phosphates: the $\delta^{18} \mathrm{O}$ of coexisting fishes and mammals of the middle Miocene sea of western France, Palaeogeogr. Palaeocl., 126, 61-74, https://doi.org/10.1016/S00310182(96)00070-3, 1996.

Lécuyer, C., Amiot, R., Touzeau, A., and Trotter, J.: Calibration of the phosphate $\delta^{18} \mathrm{O}$ thermometer with carbonate-water oxygen isotope fractionation equations, Chem. Geol., 347, 217-226, https://doi.org/10.1016/j.chemgeo.2013.03.008, 2013.

Le Hon, H.: Préliminaires d'un mémoire sur les poissons tertiaires de Belgique, H. Merzbach, Brussels, 1871.

Leriche, M.: Contribution à L'étude des poissons fossils des pays riverains de la Méditerranée américaine, Venezuela, Trinité, Antiles, Mexique, Mémoires de la Sociéte Paléontologique du Suisse, 61, 1-52, 1938.

Leuzinger, L., Kocsis, L., Billon-Bruyat, J.-P., Spezzaferri, S., and Vennemann, T.: Stable isotope study of a new chondrichthyan fauna (Kimmeridgian, Porrentruy, Swiss Jura): an unusual freshwater-influenced isotopic composition for the hybodont shark Asteracanthus, Biogeosciences, 12, 6945-6954, https://doi.org/10.5194/bg-12-6945-2015, 2015.
Linck, H. F.: Versuch einer Eintheilung der Fische nach den Zähnen, Magazin für das Neueste aus der Physik und Naturgeschichte, 6, 28-38, 1790 .

Lockwood, J. P.: Geology of the Serranía de Jarara Area. Guajira Peninsula, Colombia, PhD thesis, Princeton University, Princeton, New Jersey, 1965.

Longinelli, A. and Nuti, S.: Revised phosphate-water isotopic temperature scale, Earth Planet. Sc. Lett., 19, 373-376, https://doi.org/10.1016/0012-821X(73)90088-5, 1973a.

Longinelli, A. and Nuti, S.: Oxygen isotope measurements of phosphate from fish teeth and bones, Earth Planet. Sc. Lett., 20, 337 340, https://doi.org/10.1016/0012-821X(73)90007-1, 1973 b.

Matich, P. and Heithaus, M.: Multi-tissue stable isotope analysis and acoustic telemetry reveal seasonal variability in the trophic interactions of juvenile bull sharks in a coastal estuary, J. Anim. Ecol., 83, 199-213, https://doi.org/10.1111/1365-2656.12106, 2013.

Mine, A. H., Waldeck, A., Olack, G., Hoerner, M. E., Alex, S., and Colman, A. S.: Microprecipitation and $\delta^{18} \mathrm{O}$ analysis of phosphate for paleoclimate and biogeochemistry research, Chem. Geol., 460, 1-14, https://doi.org/10.1016/j.chemgeo.2017.03.032, 2017.

Montes, C., Cardona, A., Jaramillo, C., Pardo, A., Silva, J. C., Valencia, V., Ayala, C., Pérez-Angel, L. C., Rodriguez-Parra, L. A., Ramirez, V., and Niño, H.: Middle Miocene closure of the Central American Seaway, Science, 348, 226-229, 2015.

Moreno, F., Hendy, A. J. W., Quiroz, L., Hoyos, N., Jones, D. S., Zapata, V., Zapata, S., Ballen, G. A., Cadena, E., Cárdenas, A. L., Carrillo-Briceño, J. D., Carrillo, J. D., Delgado-Sierra, D., Escobar, J., Martínez, J. I., Martínez, C., Montes, C., Moreno, J., Pérez, N., Sánchez, R., Suárez, C., Vallejo-Pareja, M. C., and Jaramillo, C.: Revised stratigraphy of Neogene strata in the Cocinetas Basin, La Guajira, Colombia, Swiss Journal of Palaeontology, 134, 5-43, 2015.

Moreno-Bernal, J. W., Head, J., and Jaramillo, C.: Fossil Crocodilians from the High Guajira Peninsula of Colombia: Neogene faunal change in northernmost South America, J. Vertebr. Paleontol., 36, e1110586, https://doi.org/10.1080/02724634.2016.1110586, 2016.

Müller, A.: Ichthyofaunen aus dem atlantischen Tertiär der USA, Leipziger Geowissenschaften, 9-10, 1-360, 1999.

Müller, J. and Henle, J.: Gattungen der Haifische und Rochen nach einer von ihm mit Hrn. Henle unternommenen gemeinschaftlichen Arbeit über die Naturgeschichte der Knorpelfische, Akademie der Wissenschaften zu Berlin, 1837, 111-118, 1837.

Müller, J. and Henle, J.: Systematische Beschreibung der Plagiostomen, Veit, Berlin, 1838-1841.

O’Neil, J. R., Roe, L. J., Reinhard, E., and Blake, R. E.: A rapid and precise method of oxygen isotope analysis of biogenic phosphate, Israel J. Earth Sci., 43, 203-212, 1994.

Patnaik, R., Milankumar-Sharma, K., Mohan, L., Williams, B. A., Kay, R. F., and Chatrath, P.: Additional vertebrate remains from the early Miocene of Kutch, Gujarat, Special Publication of the Paleontological Society of India, 5, 335-351, 2014.

Pérez, M. E., Vallejo-Pareja, M. C., Carrillo, J. D., and Jaramillo, C.: A new Pliocene Capybara (Rodentia, Caviidae) from northern South America (Guajira, Colombia), and its implications for the Great American Biotic Interchange, J. Mamm. Evol., 24, 111$125,2016$. 
Pérez-Consuegra, N., Parra, M., Jaramillo, C., Silvestro, D., Echeverri, S., Montes, C., Jaramillo, J. M., and Escobar, J.: Provenance analysis of the Pliocene Ware Formation in the Guajira Peninsula, northern Colombia: Paleodrainage implications, J. S. Am. Earth Sci., 81, 66-77, https://doi.org/10.1016/j.jsames.2017.11.002, 2018.

Pimiento, C., Gonzalez-Barba, G., Hendy, A. J. W., Jaramillo, C., MacFadden, B. J., Montes, C., Suarez, S. C., and Shippritt, M.: Early Miocene chondrichthyans from the Culebra Formation, Panama: a window into marine vertebrate faunas before closure the Central American Seaway, J. S. Am. Earth Sci., 42, 159-170, 2013.

Poey, F.: Synopsis piscium cubensium. Catalogo razonado de los peces de la isla de Cuba, Repertorio Fisico-Natural de la Isla de Cuba, 2, 279-484, 1868.

Poey, F.: Enumeratio piscium cubensium (Parte III), Anales de la Sociedad Española de Historia Natural, 5, 373-404, 1876.

Probst, J.: Beiträge zur Kenntniss der fossilen Fische aus der Molasse von Baltringen. Hayfische, Jahreshefte des Vereins für vaterländische Naturkunde in Württemberg, 35, 127-191, 1879.

Pucéat, E., Joachimski, M., Bouilloux, A., Monna, F., Bonin, A., Montreuil, S., Morinière, P., Hénard, S., Mourin, J., Dera, G., and Quesne, D.: Revised phosphate-water fractionation equation reassessing paleotemperatures derived from biogenic apatite, Earth Planet. Sc. Lett.s, 298, 135-142, https://doi.org/10.1016/j.epsl.2010.07.034, 2010.

Purdy, R., Clellan, J. H. M., Schneider, V. P., Applegate, S. P., Meyer, R., and Slaughter, R.: The Neogene sharks, rays and bony fishes from Lee Creek Mine, Aurora, North Carolina, in: Geology and paleontology of the Lee Creek Mine, North Carolina, III, edited by: Ray, C. E. and Bohaska, D. J., Smithsonian Contributions to Paleobiology, 90, Smithsonian Institution Press, Washington D.C., 71-202, 2001.

Putman, R. J. and Wratten, S. D.: Species Diversity, in: Principles of Ecology, edited by: Putman, R. J. and Wratten, S. D., University of California Press, Berkeley and Los Angeles, 320-337, 1984.

Rafinesque, C. S.: Caratteri di alcuni nuovi generi e nuove specie di animali e piante della Sicilia con varie osservazioni sopra i medesimi, Per le stampe di Sanfilippo, Palermo, 1810.

Reinecke, T., Louwye, S., Havekost, U., and Moths, H.: The elasmobranch fauna of the late Burdigalian, Miocene, at WerderUesen, Lower Saxony, Germany, and its relationships with early Miocene faunas in the North Atlantic, Central Paratethys and Mediterranean, Palaeontos, 20, 1-170, 2011.

Reinecke, T., Balsberger, M., Beaury, B., and Pollerspöck, J.: The elasmobranch fauna of the Thalberg Beds, early Egerian (Chattian, Oligocene), in the Subalpine Molasse Basin near Siegsdorf, Bavaria, Germany, Palaeontos, 26, 1-127, 2014.
Reis, M. A. F.: Chondrichthyan fauna from the Pirabas Formation, Miocene of northern Brazil, with comments on paleobiogeography, Anuário do Instituto de Geociências, 28, 31-58, 2005.

Rodríguez, G.: The Maracaibo System, Venezuela, in: Coastal Marine Ecosystems of Latin America, edited by: Seeliger, U. and Kjerfve, B., Ecological Studies, Springer Berlin Heidelberg, 144, 47-60, 2001.

Rüppell, W. P. E. S. E.: Fische des Rothen Meeres, Frankfurt am Main, Frankfurt, 1837.

Santos, R. S. and Travassos, H.: Contribuição à Paleontologia do estado do Pará, Peixes fósseis da Formação Pirabas, Serviço gráfico do Instituto Brasileiro de Geografia e Estatística, Rio de Janeiro, 1960.

Silva-Tamayo, J. C., Lara, M. E., Yobo, L. N., Erdal, Y. D., Sanchez, J., and Zapata-Ramirez, P. A.: Tectonic and environmental factors controlling on the evolution of Oligo-Miocene shallow marine carbonate factories along a tropical SE Circum-Caribbean, J. S. Am. Earth Sci., 78, 213-237, 2017.

Tavares, R. and Sánchez, L.: Áreas de cría de tiburones en el Golfo de Venezuela, Ciencia, 20, 116-124, 2012.

Vennemann, T., Hegner, E., Cliff, G., and Benz, G. W.: Isotopic composition of recent shark teeth as a proxy for environmental conditions, Geochim. Cosmochim. Ac., 65, 1583-1599, https://doi.org/10.1016/S0016-7037(00)00629-3, 2001.

Vennemann, T., Fricke, H. C., Blake, R. E., O’Neil, J. R., and Colman, A.: Oxygen isotope analysis of phosphates: a comparison of techniques for analysis of $\mathrm{Ag}_{3} \mathrm{PO}_{4}$, Chem. Geol., 185, 321-336, https://doi.org/10.1016/S0009-2541(01)00413-2, 2002.

Voigt, M. and Weber, D.: Field guide for sharks of the genus Carcharhinus, Verlag Dr. Friedrich Pfeil, München, 2011.

Ward, D. and Bonavia, C.: Additions to, and a review of, the Miocene shark and ray fauna of Malta, The Central Mediterranean Naturalist, 3, 131-146, 2001.

White, W. T. and Naylor, G. J.: Resurrection of the family Aetobatidae (Myliobatiformes) for the pelagic eagle rays, genus Aetobatus, Zootaxa, 4139, 435-438, 2016.

Woodward, A. S.: Catalogue of the fossil fishes in the British Museum. Part I, British Museum (Natural History), London, 1889.

Zazzo, A., Lécuyer, C., and Mariotti, A.: Experimentallycontrolled carbon and oxygen isotope exchange between bioapatites and water under inorganic and microbiallymediated conditions, Geochim. Cosmochim. Ac., 68, 1-12, https://doi.org/10.1016/S0016-7037(03)00278-3, 2004a.

Zazzo, A., Lécuyer, C., Sheppard, S. M. F., Grandjean, P., and Mariotti, A.: Diagenesis and the reconstruction of paleoenvironments: a method to restore original $\delta^{18} \mathrm{O}$ values of carbonate and phosphate from fossil tooth enamel, Geochim. Cosmochim. Ac., 68 , 2245-2258, https://doi.org/10.1016/j.gca.2003.11.009, 2004b. 